\title{
A Cross-Country Empirical Analysis of International Reserves
}

\author{
YIN-WONG CHEUNG \\ HIRO ITO
}

\begin{abstract}
CESIFO WORKING PAPER NO. 2654
CATEgORY 7: MONETARy POLICY AND INTERNATIONAL FinANCE

MAY 2009
\end{abstract}
An electronic version of the paper may be downloaded
- from the SSRN website:
- from the RePEc website:
www.SSRN.com
- from the CESifo website:
www.RePEc.org
www.CESifo-group.org/wp




\title{
A Cross-Country Empirical Analysis of International Reserves
}

\begin{abstract}
Using data from more than 100 economies for the period of 1975 to 2005 , we conduct an extensive empirical analysis of the determinants of international reserve holdings. Four groups of determinants, namely, traditional macro variables, financial variables, institutional variables, and dummy variables that control for individual economies' characteristics are considered. We find that the relationship between international reserves and their determinants is significantly different between developed and developing economies and is not stable over time. The estimation results indicate that, especially during the recent period, a developed economy tends to hold a lower level of international reserves than a developing one. Furthermore, there is only limited evidence that East Asian economies including China and Japan are accumulating an excessive amount of international reserves.
\end{abstract}

JEL Code: F31, F34, F36.

Keywords: developed vs developing economies, excess hoarding, macro determinants, financial factors, institutional variables.

\author{
Yin-Wong Cheung \\ Department of Economics, E2 \\ University of California \\ USA - Santa Cruz, CA 95064 \\ cheung@ucsc.edu
}

\author{
Hiro Ito \\ Department of Economics \\ Portland State University \\ 1721 SW Broadway \\ USA - Portland, OR 97201 \\ ito@pdx.edu
}

May 2009

We thank Menzie Chinn, Joseph Gruber, Jie Li, Helen Popper, Cedlic Tille, and participants of the 2006 APEA conference and the 2007 Claremont-Bologna-Singapore Centre for Applied and Policy Economics (SCAPE) International Economic Policy Forum for their helpful comments and suggestions, Dickson Tam for compiling some of the data, and Philip Lane and Gian Maria Milesi-Ferreti for making their data on external financial wealth available online. Cheung and Ito acknowledge the financial support of faculty research funds of the University of California, Santa Cruz and Portland State University, respectively. Ito also thanks the Japan Foundation for financial support and Lakin Garth for excellent research assistance. 


\section{Introduction}

The recent Asian financial crisis has rekindled considerable interest in examining the behavior of international reserve hoarding. The fundamental rationale for holding international reserves ranges from transaction demand, precautionary motives, collateral asset argument, and mercantilist behavior. Although numerous studies have attempted to unravel the relevance of these factors, the debate on the determinants of international reserves is far from settled. The difficulty of explicating international reserve holding behavior may be attributed to the anecdotal view that the role and functionality of international reserves have evolved along with developments in global financial markets. For instance, the holding of international reserves is now increasingly susceptible to capital account transactions because of the continuing financial globalization and innovative advancements in international capital markets. The recent financial crisis also signified the importance of expectations, policy credibility, and institutional structures in determining the adequate level of international reserves. ${ }^{1}$

One of the unique features of the Asian financial crisis is that some economies in the region have been accumulating international reserves at an astonishing rate in the aftermath of the event. The first few years of the $21^{\text {st }}$ century have witnessed an unprecedented growth of global international reserves - a growth rate of over 114.9\% between 2000 and 2006, which was driven by a handful of economies. During the period, China, Japan, Korea, Malaysia and Taiwan have increased their international reserve holdings by 449\%, 114\%, 115\%, 151\% and 115\%, respectively. $^{2}$ Figure 1 presents the evolution of international reserve holdings by the world and some selected economies.

The phenomenal build-up by these economies has revived research interest in the determinants of international reserves. Some studies focus on the buffer-stock and precautionary demand motivation and incorporate the crisis-induced costs of output and investment contractions (Aizenman et al. 2007; Lee, 2004). Dooley et al. (2005), in a series of papers, resurrects the mercantilist view and suggest that international reserve accumulation in East Asia is a consequence of export-oriented growth strategy and the absence of a well-functioning domestic and/or regional financial system. Aizenman and Lee (2007) empirically confirm the

\footnotetext{
$1 \quad$ Some recent studies on the recent crisis are Krugman (1999), Corsetti, Pesenti and Roubini (1999), Chang and Velasco (1999) and Dooley (2000).

Japan, China, and Russia are the three largest holders of international reserves as of 2006. During this period, Russia and India increased international reserves by 933\% and 286\%, respectively. Some developed countries also experienced a sharp increase such as Australia (154.4\%) and Denmark (69.9\%).
} 
mercantilist motivation, but find that, compared with the precautionary demand, the mercantilist motivation accounts for a relatively small amount of international reserve hoarding. Other determinants for international reserve holding considered in recent studies include short-term external debts, financial development, and political and institutional factors. ${ }^{3}$

Figure 1: International Reserves - the World and Selected Economies

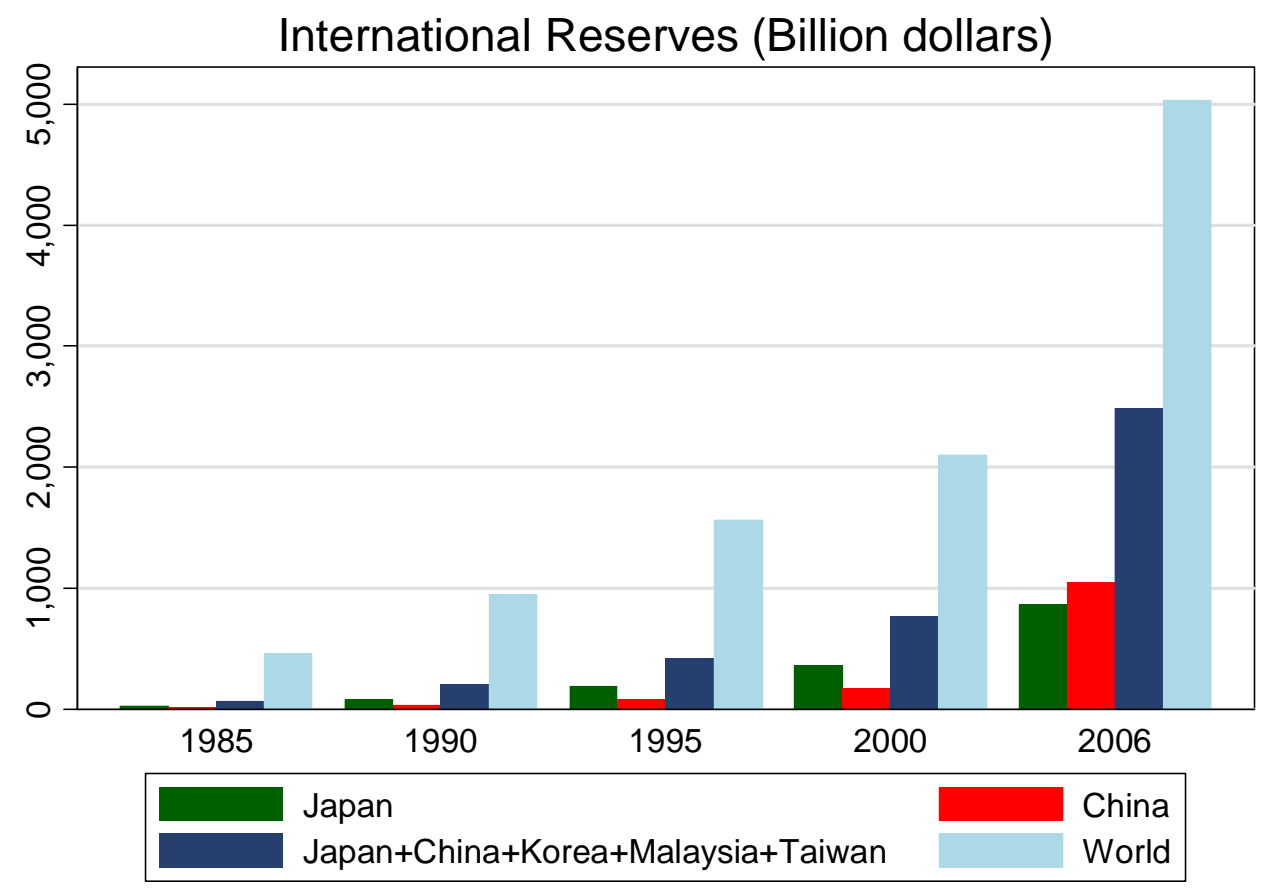

Source: IFS

Note: The Chinese figures do not include Hong Kong’s.

The recent developments in the literature on international reserves have raised a few questions. For instance, to what extent do these new factors help us understand the observed holding of international reserves? Are these new factors complements or substitutes for the "old" traditional economic variables? Do these new factors explain observed holdings of international reserves even before they were identified in the literature? Have the determinants of international reserve holding changed over time? Answers to these questions should shed some insight on the evolution of the behavior of demand for international reserves. In addition, an empirical analysis should allow us to assess whether economies are holding deficient or excessive levels of international reserves.

3 See, for example, Aizenman and Marion (2001, 2003, 2004), Alfaro, et al. (2003), and Greenspan (1999). 
To investigate these questions, we conduct an extensive empirical analysis using data from more than 100 economies during the period of 1975 to 2005. In designing the empirical architecture, we take into account of some known results in the literature. For instance, previous studies have documented that developed and developing economies display different demand for international reserves (Frenkel 1974a). Others have evidenced that the nature of the demand behaviors for international reserves has changed in the presence of significant historical events such as the breakdown of the Bretton Woods system and oil crises (Bahmani-Oskooee, 1988; Frenkel, 1980; Lizondo and Mathieson 1987). Most recently, Aizenman et al. (2007) also identify structural changes in the Korean international reserve holding after the Asian financial crisis. Hence, in this study, we sort the economies into two groups, the developed and developing economies, and investigate the determinants of the demand for international reserves in non-overlapping sample periods that are partitioned by major crisis episodes.

Following the development in the theoretical literature, we consider four groups of explanatory variables: traditional macro variables, financial variables, institutional variables, and dummy variables that control for individual economies' characteristics. To anticipate the results, we confirm that the demand for international reserves of developed economies is different from that of developing economies. The set of (significant) explanatory variables also changes across different sample periods. There is evidence that the holding pattern of international reserves has been affected by the occurrences of the debt crisis in the 1980s, and the Tequila crisis and the Asian crisis in the 1990s.

Among all the factors we considered, the propensity to import, a proxy for trade openness, garners the largest number of significant coefficient estimates across different specifications and sample periods. However, its explanatory power has been declining over time for both developed and developing economies. On the other hand, the explanatory power of financial variables, including those related to external financing, has been increasing over time.

Our evidence suggests that, compared with developing economies, the developed economies enjoy a “premium” in accumulating international reserves since the early 1980s - that is, they could afford to hold lower levels of international reserves, ceteris paribus. Moreover, our estimation results present only limited evidence that East Asian economies including China and Japan are hoarding an excessive amount of international reserves.

A brief review of these determinants of international reserves is given in the next section. 
Section 3 contains the main regression results. It presents the empirical framework and discusses results from different sample periods and different country groups. Additional analyses are reported in Section 4. Specifically, we compare the patterns of international reserve holdings between developed and developing economies. Also, in view of the recent debate, we assess whether some economies are holding an excessively high level of international reserves in the recent period. Concluding remarks are offered in Section 5.

\section{A Brief Review on the Determinants of International reserves}

To trace theoretical developments and to facilitate comparison, we group the determinants of international reserves into three categories: traditional macro variables, financial variables, and institutional variables, Readers familiar with the effects of these variables may choose to proceed directly to Section 3.

The group of traditional macro variables consists of the propensity to import, volatility of real export receipts, international reserve volatility, the opportunity cost of holding international reserves, real per capita GDP, and population. These variables have been commonly considered as determinants since the 1960s. In the early stage of theorization, the demand for international reserves is mainly attributed to the need for accommodating imbalances arising from trade account transactions, which are the main type of balance of payments transactions before the development of the modern international capital market.

Heller (1966) argues that the demand for international reserves should be negatively related to the marginal propensity to import because a higher propensity to import $(\mathrm{m})$ implies a smaller marginal cost of balance of payments adjustment (i.e., $1 / \mathrm{m}$ ), and, thereby, a lower demand for international reserves. However, most empirical exercises - including Heller (1966) himself - use the average, and not the marginal, propensity to import. Frenkel (1974b) points out that the average propensity to import, i.e., the imports-to-GDP ratio, measures trade openness and, therefore, should have a positive effect on the demand for international reserves because of the precautionary holding to accommodate external shocks through trade channels.

The role of international reserve volatility is illustrated by the buffer stock model of international reserves. Extending the model for cash holding, Frenkel and Jovanovic (1981) illustrate the effect of international reserve volatility in a stochastic inventory control setting. In some studies, the volatility of real export receipts is used as an alternative proxy for the 
uncertainty of balance of payments (Kelly, 1970).

The opportunity cost of holding international reserves, which is commonly measured by the difference between the local interest rate and the US interest rate, has been included in models that compare the costs and benefits of holding international reserves (Heller, 1966; Frenkel and Jovanovic, 1981). The effect of the opportunity cost is quite inconspicuous in the empirical literature, mainly due to the difficulty in assigning a single interest rate for international reserve assets while accounting for their risks. ${ }^{4}$

Following Aizenman and Marion (2003), Edison (2003), and Lane and Burke (2001), real per capita GDP and population are included to capture the size effect on international reserve holding. In view of the Baumol (1952) square-root rule for transaction demand, we expect these size variables to have a negative coefficient.

The second group of explanatory variables includes money supply, external debts, and capital flows. The use of money in explaining the hoarding of international reserves can be dated back to the 1950s. Courchene and Youssef (1967), for example, appeal to the monetarist model of balance of payments to justify the use of money in their international reserve regression. ${ }^{5}$ More recently, de Beaufort Wijnholds and Kapteyn (2001) argue that money stock in an economy is a proxy for potential capital flight by domestic residents and, therefore, can be a measure of the intensity of the "internal drain."6

The implications of external debts and capital flows on the holding of international reserves have received considerable attention after the Asian financial crisis. While capital inflows can enhance economic growth by supplementing domestic savings and/or financial intermediaries and improving the efficiency of domestic financial markets, a sudden capital flow reversal can devastate an economy, trigger a crisis, and cause significant output losses. ${ }^{7}$ Generally, developing economies with inefficient and immature financial sectors are vulnerable

\footnotetext{
$4 \quad$ Sometimes, the difference between the yields on the US and domestic government bonds is used to capture the opportunity cost effect. In our exercise, due to data availability, we use the differentials between the U.S. Treasury bill rates and domestic lending rates.

5 One version of the "global monetarism" argues that an increase in international reserves is driven by an excess demand for money, which implies a balance of payments surplus whereas a fall in international reserve holding is caused by an excess supply of money, which implies a balance of payments deficit (Johnson, 1958). $6 \quad$ de Beaufort Wijnholds and Kapteyn (2001) refer to the research on the Early Warning System and argue that the international reserves-to-M2 ratio is a reasonable measure of international reserve adequacy.

$7 \quad$ Edwards (2004) analyzes the sudden stop of capital inflows and current account performance in the last three decades. Caballero and Panageas (2004) suggest that international reserve accumulation is not the best insurance against sudden stops.
} 
to the adverse effect of capital reversals. Thus, it is conceived that economies with a high level of exposure to external financing, whether they are debts, FDI, or portfolio flows, should hold a high level of international reserves to reduce its vulnerability to financial crises and to boost confidence in their currencies (Aizenman et al., 2007; Feldstein, 1999). ${ }^{8}$

Dooley, et al. (2005) offers an alternative view on the link between capital flows and international reserves. These authors argue that under the current international financial architecture (the "Bretton Woods II system”), emerging market economies accumulate international reserves to secure FDI inflows from the center country, i.e., the United States. In other words, the economies in the "periphery" hold international reserves to ensure importation of financial intermediaries from abroad. According to this view, capital inflows are positively correlated with holdings of international reserves.

The effect of capital flows on international reserve accumulation, however, is not unambiguous. Besides the insurance motive, international reserves can be viewed as a substitute for external financing. In this case, an economy may hold a lower level of international reserves if it has secured access to international capital markets and, thus, the correlation between the two variables is expected to be negative.

Lane and Milesi-Ferretti (2006) note that the types, volumes, and directions of capital flows have changed over time. Hence, the use of an aggregate variable may not capture the differential effects of different types of capital flows. In the following, we examine the individual effects of net external liabilities (i.e., external liabilities minus assets) in debt financing, portfolio equity financing, and FDI, as well as their growth rates.

The third group of explanatory variables is institutional variables. It has been argued that institutional characteristics such as corruption, political stability, and capital controls affect the holding of international reserves. Aizenman and Marion (2003, 2004) and Alfaro et al. (2003), for example, show that holdings of international reserves are influenced by political uncertainty and corruption. Our empirical exercise includes a selected group of institutional variables pertaining to financial openness and political/societal conditions.

In addition to these three groups of explanatory variables, our sample also includes four types of dummy variables to account for other characteristics of the economies. The first type is

$8 \quad$ In general, it is suggested to cover one year amortized value of various types of liabilities over a wide range of possible outcomes. The role of short-term external debts is brought to the center stage by the popular Greenspan-Guidotti-rule (Greenspan, 1999). 
the exchange rate regime dummy variable. ${ }^{9}$ The common wisdom suggests that economies with fixed exchange rates and crawling pegs have incentives to hold international reserves to fight against exchange rate market pressures. ${ }^{10}$ The second type is a geographic dummy variable. Its inclusion is motivated by the folklore that economies in certain geographic regions such as East Asia tend to hoard high levels of international reserves especially after the Asian financial crisis. The third type is the crisis dummy variable. The variable is meant to capture the effects of a currency crisis, a banking crisis, or a twin crisis on hoarding of international reserves. ${ }^{11}$ The fourth type is an interaction variable that assumes a value of one if the economy is located in a region which is inflicted by a crisis. This dummy variable is included to evaluate the possible contagion effect of crises on international reserves accumulation.

\section{Empirical Analysis}

\subsection{Model Specifications}

In the following empirical exercise, we consider a normalized international reserve variable given by $r_{i, t}=R_{i, t} / G D P_{i, t}$, where $R_{i, t}$ is a generic notation of economy $i$ 's holding of international reserves and $G D P_{i, t}$ is economy $i$ 's gross domestic product at time $t$. Both variables are measured in U.S. dollars. Scaling international reserves facilitates comparison across countries of different sizes. For brevity, we call the ratio $r_{i, t}$ international reserves. The three types of determinants of international reserves are denoted by $X_{i, t}\left(=\left\{x_{i, k, t} ; k=1, \ldots, N_{x}\right\}\right)$ which contains the traditional macro variables, $Y_{i, t}\left(=\left\{y_{i, k, t} ; k=1, \ldots, N_{y}\right\}\right)$ the financial variables, and $Z_{i, t}$

$9 \quad$ Frenkel (1980) and Flood and Marion (2002), for example, report that exchange rate arrangements have effects on the holding of international reserves. Lane and Burke (2001), on the other hand, find no significant association between exchange rate regimes and international reserves.

10 In this study, the Reinhart-Rogoff (2002) index is used to construct the exchange rate regime dummy variable. Their index ranges from 1 "no separate legal tender," to 14 "Freely falling” (with increasing flexibility of exchange rate movement) and is a "de facto" index in contrast to IMF's "de jure" exchange rate regime classification. In this paper, we aggregate these categories into three; namely "floating," "Crawling Peg,” and "Fixed/Pegged."

11 The currency crisis dummy variable is derived from the conventional exchange rate market pressure (EMP) index pioneered by Eichengreen et al. (1996). The EMP index is defined as a weighted average of monthly changes in the nominal exchange rate, the international reserve loss in percentage, and the nominal interest rate. The weights are inversely related to the pooled variance of changes in each component over the sample countries, and adjustment is made for the countries that experienced hyperinflation following Kaminsky and Reinhart (1999). For countries without data to compute the EMP index, the currency crisis classifications in Glick and Hutchison (2001) and Kaminsky and Reinhart (1999) are used. The banking crisis dummy variable is based on Caprio and Klingebiel (2003). The twin crisis effect is examined by an interaction variable between a currency crisis and a banking crisis (Hutchison and Noy, 2002). 
$\left(=\left\{z_{i, k, t} ; k=1, \ldots, N_{z}\right\}\right)$ the institutional variables. The dummy variables that capture other characteristics of the economies are collected under $D_{i, t}\left(=\left\{d_{i, k, t} ; k=1, \ldots, N_{d}\right\}\right)$. The Appendix provides a complete list of variables, their definitions, their sources, and a description of their period averages.

We consider cross-sectional behavior for three non-overlapping sample periods; namely 1975-1981, 1983-1993, and 1999-2005. The sample periods exclude the years inflicted by the three major financial crises; the Mexican debt crisis of 1982, the 1994 Tequila crisis, and the 1997-8 Asian financial crisis. ${ }^{12}$ For each of the three sample periods, we employ the period averages of $r_{i, t}, X_{i t}, Y_{i, t}, Z_{i, t}$, and $D_{i, t}$ and label them $r_{i}, X_{i}, Y_{i}, Z_{i}$, and $D_{i}$, respectively. The use of period averages allows us to avoid complexity that arises from unknown and, possibly varying dynamics, and focus on the (time-)average behavioral relationship.

The effects of these variables on hoarding of international reserves are studied using the following regression equations:

$$
\begin{aligned}
& r_{i}=c+X_{i}^{\prime} \alpha+\varepsilon_{i}, \\
& r_{i}=c+X_{i}^{\prime} \alpha+D_{i}^{\prime} \delta+\varepsilon_{i}, \\
& r_{i}=c+X_{i}^{\prime} \alpha+Y_{i}^{\prime} \beta+D_{i}^{\prime} \delta+\varepsilon_{i}, \text { and } \\
& r_{i}=c+X_{i}^{\prime} \alpha+Y_{i}^{\prime} \beta+Z_{i}^{\prime} \gamma+D_{i}^{\prime} \delta+\varepsilon_{i} .
\end{aligned}
$$

The coefficient vectors $\alpha, \beta, \gamma$, and $\delta$ are conformable to the associated explanatory variables. The intercept and disturbance term are given by $c$ and $\varepsilon_{i}$, respectively.

Specification (1) is an international reserve demand equation of the 1970s vintage. The economy characteristic dummy variables are included in specification (2). Specification (3) includes the financial variables $\left(Y_{i}\right)$ that are often referred to in the recent discussion on the demand for international reserves. The effects of institutional factors $\left(Z_{i}\right)$ are examined in specification (4). These four specifications allow us to gauge the relative and incremental contributions of the different groups of explanatory variables.

We divide the sample of 126 economies into two groups: one with 22 developed

$12 \quad$ We leave out the two years between the 1994 and 1997-98 crises since they are too short for a serious investigation. In subsection 3.3, we present robust test results from the samples that encompass the left-out period. 
economies and the other with 104 developing economies. Due to data availability, the actual number of the economies included in the estimation varies across the three sample periods, but for any given sample period, it is set fixed across the four specifications to facilitate comparison.

\subsection{Estimation Results}

The estimation results for the developed economies are presented in Table 1-1. The results pertaining to the regression equations (1) to (4) are respectively presented under the columns labeled (1) to (4) for each of the three periods; namely 1975-1981, 1983-93, and 1999-2005. We estimated these specifications sequentially and kept only significant variables in each step. Those for the developing economies are presented in the same format in Table $1-2{ }^{13}$

\subsubsection{The 1975-1981 Period}

For the developed economies, two traditional macro variables, real per capita GDP and the propensity to import, are found to be significant in the $1975-81$ period and explain $47 \%$ of variations in international reserves held by the developed economies. The signs of coefficient estimates are consistent with those predicted in the literature. The transaction demand for international reserves, on a per capita basis, falls as the real per capita income level rises (Heller 1968). The proxy for trade openness and the degree of external vulnerability given by the (average) propensity to import has the expected positive coefficient (Frenkel, 1974b).

The significant 1982 crisis dummy variable indicates that, in retrospect, the developed economies that experienced a currency crisis in 1982 held lower levels of international reserves than the non-crisis economies before the event.

The significant money effect (M2/GDP) is in accordance with the monetary interpretation of the balance of payments and also with the view that money supply is a proxy for internal drain of international reserves during the crisis period. Nonetheless, we are not sure to what extent the internal drain interpretation is relevant for these economies. In any case, inclusion of M2 leads to a noticeable increase in the adjusted R-square coefficient.

Interestingly, for this group of economies, institutional development does not have an effect on the behavior of international reserves holding back in 1975-81. Thus, the specification

13 The economies included under each of these periods are listed in the Appendix. 
Table 1-1: Estimation Results for Developed economies; 1975 - 1981, 1983 - 1993, 1999 - 2005

\begin{tabular}{|c|c|c|c|c|c|c|c|c|c|c|c|c|}
\hline & \multicolumn{4}{|c|}{$1975-1981$} & \multicolumn{4}{|c|}{$1983-1993$} & \multicolumn{4}{|c|}{$1999-2005$} \\
\hline & (1) & (2) & (3) & (4) & (1) & $(2)$ & (3) & (4) & (1) & (2) & (3) & (4) \\
\hline Real per capita GDP & $\begin{array}{c}-0.107 \\
{[0.057]^{*}}\end{array}$ & $\begin{array}{c}-0.13 \\
{[0.055]^{* *}}\end{array}$ & $\begin{array}{c}-0.131 \\
{[0.039]^{* * *}}\end{array}$ & & & & & & & & & \\
\hline Propensity to import & $\begin{array}{c}0.245 \\
{[0.055]^{* * *}}\end{array}$ & $\begin{array}{c}0.196 \\
{[0.065]^{* * *}}\end{array}$ & $\begin{array}{c}0.321 \\
{[0.055]^{* * *}}\end{array}$ & & $\begin{array}{c}0.272 \\
{[0.068]^{* * *}}\end{array}$ & $\begin{array}{c}0.3 \\
{[0.101]^{* * *}}\end{array}$ & $\begin{array}{c}0.357 \\
{[0.080]^{* * *}}\end{array}$ & $\begin{array}{c}0.444 \\
{[0.071]^{* * *}}\end{array}$ & & & & \\
\hline Population (in log) & & & & & & & & & $\begin{array}{c}-0.02 \\
{[0.007]^{* * *}}\end{array}$ & $\begin{array}{c}-0.017 \\
{[0.006]^{* *}}\end{array}$ & $\begin{array}{c}-0.017 \\
{[0.007]^{* *}}\end{array}$ & $\begin{array}{c}-0.026 \\
{[0.004]^{* * *}}\end{array}$ \\
\hline $\begin{array}{c}\text { International reserve } \\
\text { volatility }\end{array}$ & & & & & & & & & $\begin{array}{c}0.009 \\
{[0.004]^{*}}\end{array}$ & $\begin{array}{c}0.007 \\
{[0.004]} \\
\end{array}$ & $\begin{array}{c}0.007 \\
{[0.004]} \\
\end{array}$ & $\begin{array}{c}0.01 \\
{[0.003]^{* * *}}\end{array}$ \\
\hline $\begin{array}{l}\text { Crisis in } 1982 \\
\text { Fixed/Pegged regime }\end{array}$ & & $\begin{array}{c}-0.061 \\
{[0.037]^{*}}\end{array}$ & $\begin{array}{c}-0.058 \\
{[0.027]^{* *}}\end{array}$ & & & $\begin{array}{c}-0.028 \\
{[0.030]} \\
-0.029 \\
{[0.038]}\end{array}$ & $\begin{array}{c}-0.049 \\
{[0.032]} \\
-0.063 \\
{[0.025]^{* *}}\end{array}$ & $\begin{array}{c}-0.049 \\
{[0.023]^{* *}} \\
-0.089 \\
{[0.025]^{* * *}}\end{array}$ & & & & \\
\hline Crawling peg regime & & & & & & & & & & $\begin{array}{c}0.131 \\
{[0.011]^{* * *}}\end{array}$ & $\begin{array}{c}0.136 \\
{[0.010]^{* *}}\end{array}$ & $\begin{array}{c}0.122 \\
{[0.008]^{* * *}}\end{array}$ \\
\hline M2 / GDP & & & $\begin{array}{c}0.132 \\
{[0.052]^{* *}}\end{array}$ & & & & $\begin{array}{c}0.33 \\
{[0.056]^{* * *}}\end{array}$ & $\begin{array}{c}0.363 \\
{[0.060]^{* * *}}\end{array}$ & & & & \\
\hline $\begin{array}{r}\text { Net portfolio } \\
\text { liabilities }\end{array}$ & & & & & & & & & & & $\begin{array}{c}-0.018 \\
{[0.015]}\end{array}$ & $\begin{array}{c}-0.029 \\
{[0.012]^{* *}}\end{array}$ \\
\hline $\begin{array}{l}\text { Leftist government } \\
\text { De jure capital acct. } \\
\text { openness }\end{array}$ & & & & & & & & $\begin{array}{c}0.047 \\
{[0.018]^{* *}}\end{array}$ & & & & $\begin{array}{c}0.055 \\
{[0.016]^{* * *}}\end{array}$ \\
\hline Constant & $\begin{array}{c}1.044 \\
{[0.552]^{*}}\end{array}$ & $\begin{array}{c}1.283 \\
{[0.547]^{* *}}\end{array}$ & $\begin{array}{c}1.183 \\
{[0.377]^{* * *}}\end{array}$ & & $\begin{array}{c}0.022 \\
{[0.018]}\end{array}$ & $\begin{array}{c}0.022 \\
{[0.019]}\end{array}$ & $\begin{array}{c}-0.198 \\
{[0.047]^{* * *}}\end{array}$ & $\begin{array}{c}-0.257 \\
{[0.054]^{* * *}}\end{array}$ & $\begin{array}{c}0.365 \\
{[0.114]^{* * *}}\end{array}$ & $\begin{array}{c}0.321 \\
{[0.098]^{* * *}}\end{array}$ & $\begin{array}{c}0.326 \\
{[0.111]^{* *}}\end{array}$ & $\begin{array}{c}0.323 \\
{[0.040]^{* * *}}\end{array}$ \\
\hline \# Observations & 21 & 21 & 21 & & 22 & 22 & 22 & 22 & 22 & 22 & 22 & 22 \\
\hline Adj. R-square & 0.47 & 0.52 & 0.72 & & 0.18 & 0.12 & 0.72 & 0.79 & 0.28 & 0.65 & 0.65 & 0.83 \\
\hline
\end{tabular}

NOTES: Robust standard errors are given in brackets. *, **, and *** indicate significance at the $10 \%$; 5\%; and 1\% levels, respectively. The column headings (1), (2), (3), and (4) correspond to the model specifications (1), (2), (3), and (4) in the text. (4) is absent under the 1999-2005 sample period because there is no significant institutional variables. 
Table 1-2: Estimation Results for Developing economies, 1975 - 1981, 1983 - 1993, 1999 - 2005

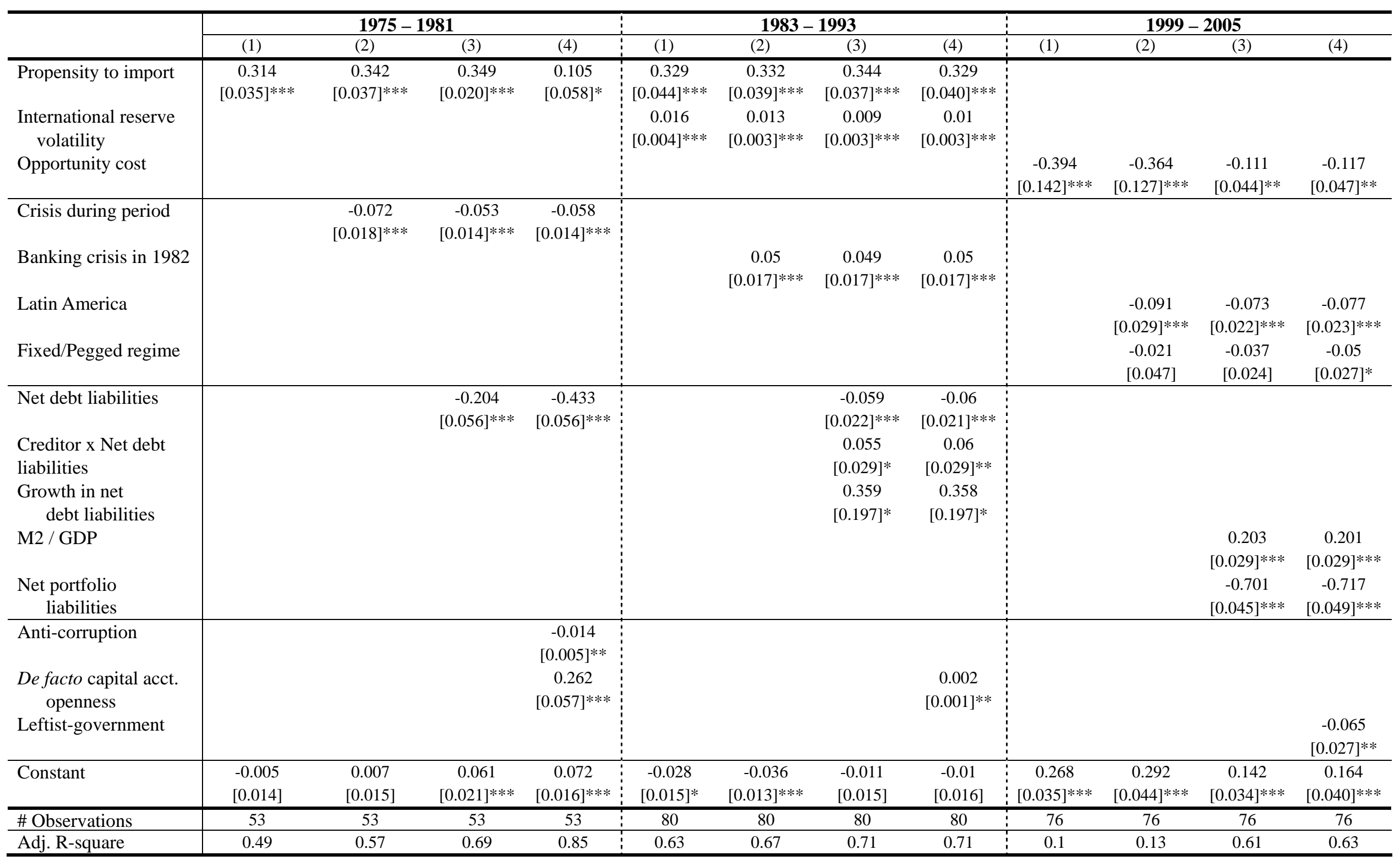

NOTES: Robust standard errors are given in brackets. *, **, and *** indicate significance at the $10 \%$; $5 \%$; and $1 \%$ levels, respectively. The column headings (1), (2), (3), and (4) correspond to the model specifications (1), (2), (3), and (4) in the text. (4) is absent under the 1999-2005 sample period because there is no significant institutional variables. 
(4) is omitted for this sample period.

For the developing economies (Table 1-2), the propensity to import again enters significantly with the expected sign. However, that is the only macroeconomic variable that enters the estimation significantly although it alone explains $49 \%$ of the variability of international reserve holdings. The result signifies the importance of trade account transactions for these economies.

The experience of a currency crisis during the period is found to be associated with a fall in the holding of international reserves. ${ }^{14}$ As the first generation crisis model predicts (Krugman, 1979; Flood and Garber, 1984), currency crises involve severe reductions in international reserves holding.

The ratio of net debt liabilities to GDP is the only significant financial variable for developing economies in this period. Neither the growth rate of net debt liabilities, nor the ratio of short-term external debts to GDP is found to be significant, suggesting that the level of external debts, but not its growth rate or its maturity structure, matters. The negative coefficient on net debt liabilities indicates that net borrowers tend to hold lower levels of international reserves. ${ }^{15}$ The evidence suggests that international reserves and external debts can be viewed as substitutes. Another possible interpretation is that higher levels of external debts increase the default risk and thus, lead to capital outflow and a drawdown of international reserves. Unfortunately, we are not able to disentangle these two interpretations. ${ }^{16}$

Two institutional variables, the indexes for corruption and de facto financial openness, are found to be significant. The effect of corruption on the holding of international reserves is different from the one reported in Aizenman and Marion (2003, 2004). ${ }^{17}$ A higher value of our corruption index means an environment less favorable to corruption. Our results indicate that a less corrupt economy holds a lower level of international reserves. A likely interpretation is that an economy with a good reputation of having less corruption would need fewer international

14 The "Dummy for crisis during the period" assigns a value of unity to economies that experienced a crisis during the 1975-81 period and, therefore, is different from the 1982 crisis dummy variable.

$15 \quad$ Positive (Negative) net external financial liabilities correspond to net receivers (providers) of external finances.

16 The use of the ratio of external debts to GDP from the World Bank/BIS/OECD dataset on external debts gives qualitatively similar results. In the text, we report results pertaining to the Lane and Milesi-Ferretti (2006) dataset because it offers a better coverage than the World Bank/BIS/OECD dataset.

$17 \quad$ To be exact, Aizenman and Marion focused on political corruption, which may have a different implication for the holding of international reserves. 
reserves to demonstrate its fundamental soundness.

It is interesting to find that financial openness (measured by the ratio of total cross-border capital flows to GDP) and international reserve holding are positively related. The result mirrors the recently advanced view that, to preempt potential capital flight, developing economies need to hold more international reserves when they are financially integrated with the global market. Our results suggest that developing economies in 1975-1981 already held international reserves in a way consistent with this type of precautionary motivation.

\subsubsection{The 1983-1993 Period}

For the developed economies in the 1983-1993 period (Table 1-1), the propensity to import is the only significant macro variable. Its coefficient estimates are generally larger than the ones in the previous sample period. Nevertheless, the variable explains a much smaller proportion of international reserve variation than the two macro variables did in the previous period.

Interestingly, economies with a fixed or peg exchange rate regime tend to hold fewer international reserves. The result follows from either a credible peg with sound economic conditions or the tendency to intervene under a non-pegged arrangement. It is likely that both reasons contribute to the observed result for the developed economies.

As it did in the previous sample period, the 1982 crisis dummy variable has negative estimates. Even though not all of them are significant, these crisis-inflicted economies tend to hold lower levels of international reserves.

The M2 variable continues to be the only significant financial variable for this group of economies while its coefficient estimates are slightly larger than those in the previous period. More importantly, inclusion of this variable improves the goodness of fit dramatically.

Among the institutional variables, the dummy variable for the economies with a leftist government enters significantly; developed economies with leftist governments hold more international reserves. This finding appears contradictory to the common belief that a leftist government tends to spend more and incur current account deficits, and thereby leads to a lower level of international reserves (Roubini and Sachs, 1989). Nonetheless, the argument is possibly more relevant to developing economies than developed ones since the former has limited access to international financing. 
Again, developing economies are also found to be driven by a different set of determinants in this period (Table 1-2). In this period, not just the propensity to import, but also international reserve volatility enters significantly. These two macroeconomic variables account for a large proportion (63\%) of cross-economy international reserve variability.

While there is no sign of a currency crisis effect, the experience of a banking crisis in 1982 is associated with an increase in the hoarding of international reserves. That is, in the aftermath of a banking crisis, the crisis-inflicted economy tends to increase its holding of international reserves. The finding is different from the crisis effect noted for developed economies in Table 1.1.

For this sample period, the data from developing economies allow us to discriminate the behaviors between net creditors and net debtors. ${ }^{18}$ That is, net debtor economies may have an incentive to hold more or fewer international reserves, depending on whether they perceive international reserves an insurance or a substitute to external finances. Net creditor developing economies, on the other hand, would not have such incentives. To this end, we create a dummy variable for net creditor economies (i.e., those with negative net debt liabilities) and interact it with the net debt liabilities variable. The effects of these variables are reported in columns (7) and (8).

The results suggest that, for the net debtor developing economies, the level of international reserves is inversely related to the amount of net liabilities; international reserves and external debts are substitutes. The coefficient estimate, however, is much smaller compared to the one from the previous sample period. Net creditor economies, on the other hand, appear to be unresponsive to net debt liabilities; the estimated coefficient on the interaction term is about the same magnitude as that of the level term with an opposite sign, indicating an essentially zero coefficient.

Besides their level, the growth of net debt liabilities is found to be a significant determinant; the faster the net liabilities increase, the more international reserves the developing economy would build up. ${ }^{19}$ According to the coefficient estimates, the net debt liabilities effect is much weaker than its growth effect. Thus, on the margin, a rise in net debt liabilities will lead to an increase in the holding of international reserves, which can be served as implicit collaterals.

\footnotetext{
18 In the 1975-1981 sample, there is no creditor developing economy.

19 The variable for the growth of net debt liabilities was also interacted with the creditor dummy variable. However, the interaction term was found to be insignificant.
} 
Among the institutional variables, only the de facto capital account openness remains to be a significant determinant - however, its magnitude is now much smaller.

\subsubsection{The 1999-2005 Period}

Population and international reserve volatility are the two significant macro determinants for the developed economies in the post-Asian financial crisis period (Table 1-1). The two variables have expected effects on the holdings of international reserves. Compared with real per capita GDP, population captures another dimension of the size effect. The negative estimates are in accordance with the perceived wisdom that the larger the population size, the smaller the (per capita) demand for international reserves would be. Also, the positive effect of international reserve volatility is consistent with the model of, say, Frenkel and Jovanovic (1981). ${ }^{20}$ In passing, we can note that a) the propensity to import is no longer a significant explanatory variable in this period, and that b) compared with macro variables in the two previous periods, these two macro variables have a fairly low explanatory power.

The crawling peg dummy variable is the only significant characteristics dummy variable. The positivity of its coefficient estimate is supportive of the "unstable middle" hypothesis, which asserts that crawling peg regimes are more prone to currency crises than flexible or fixed exchange rate regimes (Willett, 2003). The idea is that economies with crawling pegged exchange rates, and difficulties in establishing credibility, have to hold a higher level of international reserves to maintain their exchange rate regimes.

Among the financial variables, M2 (relative to GDP) is no longer significant in this period. Instead, the net value of portfolio liabilities is a significantly negative determinant. The negative sign suggests that these economies regard international reserves and portfolio flows as substitutes. The substitutability appears to be a debtor economy's phenomenon because the dummy variable for the creditor economies, those which provide portfolio financing, is not found to be significant.

The relevance of financial openness is confirmed by the significance of the Chinn-Ito index reported in column (4). ${ }^{21}$ Its positive coefficient estimate underlines the precautionary

\footnotetext{
20 A dummy variable was constructed for Japan's international reserve volatility, which is an extreme outlier.

21 A larger value of this measure means a higher level of capital account openness. The index is a reciprocal of regulatory restrictions on cross-border financial transactions and is based upon the IMF's categorical enumeration reported in Annual Report on Exchange Arrangements and Exchange Restrictions (AREAER). See Chinn and Ito
} 
motive to guard against adverse capital flows under an open capital account regime. The finding appears consistent with the recent trend of financial globalization.

Interestingly, similar to the case of developed economies, the propensity to import variable is also found to be insignificant for developing economies (Table 1-2) in the post-Asian financial crisis period. The disappearance of the significant propensity to import effect seems not to be an isolated instance. The result can be attributed to the shift of attention from trade to financial (and structural) factors occurring in the aftermath of the crisis. More data are required to assess if the absence of the propensity to import effect is a transitory or a permanent phenomenon.

The opportunity cost of holding international reserves is now the only significant macro variable - a high opportunity cost discourages the hoarding of international reserves. However, it is not clear why the cost consideration only shows up in the recent period estimation. The deterioration of the effect of macro variables is reflected by adjusted R-square estimates. The macro variable in the 1999-2005 period explains only 10\% of the variations in international reserve holdings; the lowest among the 12 cases presented in Table 1-2.

The economies in Latin America and those with pegged or fixed exchange rate systems tend to hold less international reserves. ${ }^{22}$ Among the financial variables, the M2 and the ratio of net portfolio liabilities are significant. It is the first time the M2 effect is detected for developing economies. The finding echoes the recent interpretation that money stock can be a measure of internal drain (de Beaufort Wijnholds and Kapteyn, 2001). The estimated effect of net portfolio liabilities in Table 1-2 is qualitatively similar to the one for developed economies, but is larger in magnitude. ${ }^{23}$ The result suggests that external equity financing for developing has a larger effect than for developed economies.

The significant institutional variable in this sample period is different from those in other periods in Table 1-2. During the 1999-2005 period, the developing economies with a leftist government tend to hold less international reserves. Recall that developed economies with a leftist government in the 1983 - 93 period tend to hold more international reserves (Table 1-1). As noted in the previous subsection, a negative coefficient estimate is in accordance with the

(2008) for a detailed discussion. The index is viewed as a de jure index on capital account openness.

22 The result pertaining to the Latin American economies is not driven by the crisis experienced by, say, Argentina in this period. The negative effect remains when countries like Argentina and Brazil are dummied out.

23 The interaction with the dummy variable for creditor countries is found to be insignificant. 
belief that a leftist government is with a lower level of international reserves because it tends to have large fiscal expenses and current account deficits (Roubini and Sachs, 1989). Once again, our results reveal the differences in the behaviors of developed and developing economies.

\subsection{Discussions}

\subsubsection{Varying Explanatory Power}

The estimation results show that the determinants of international reserve holding are different between developed and developing economies and vary quite substantially across different periods. The propensity to import is the variable that shows up with most significant coefficient estimates for both developed and developing economies. However, its effect virtually disappears in the post-Asian financial crisis period. Further, there is a discernable change in the coefficient estimates of the propensity to import variable across different model specifications and sample periods.

Figure 2: Incremental Explanatory Power of the Determinants

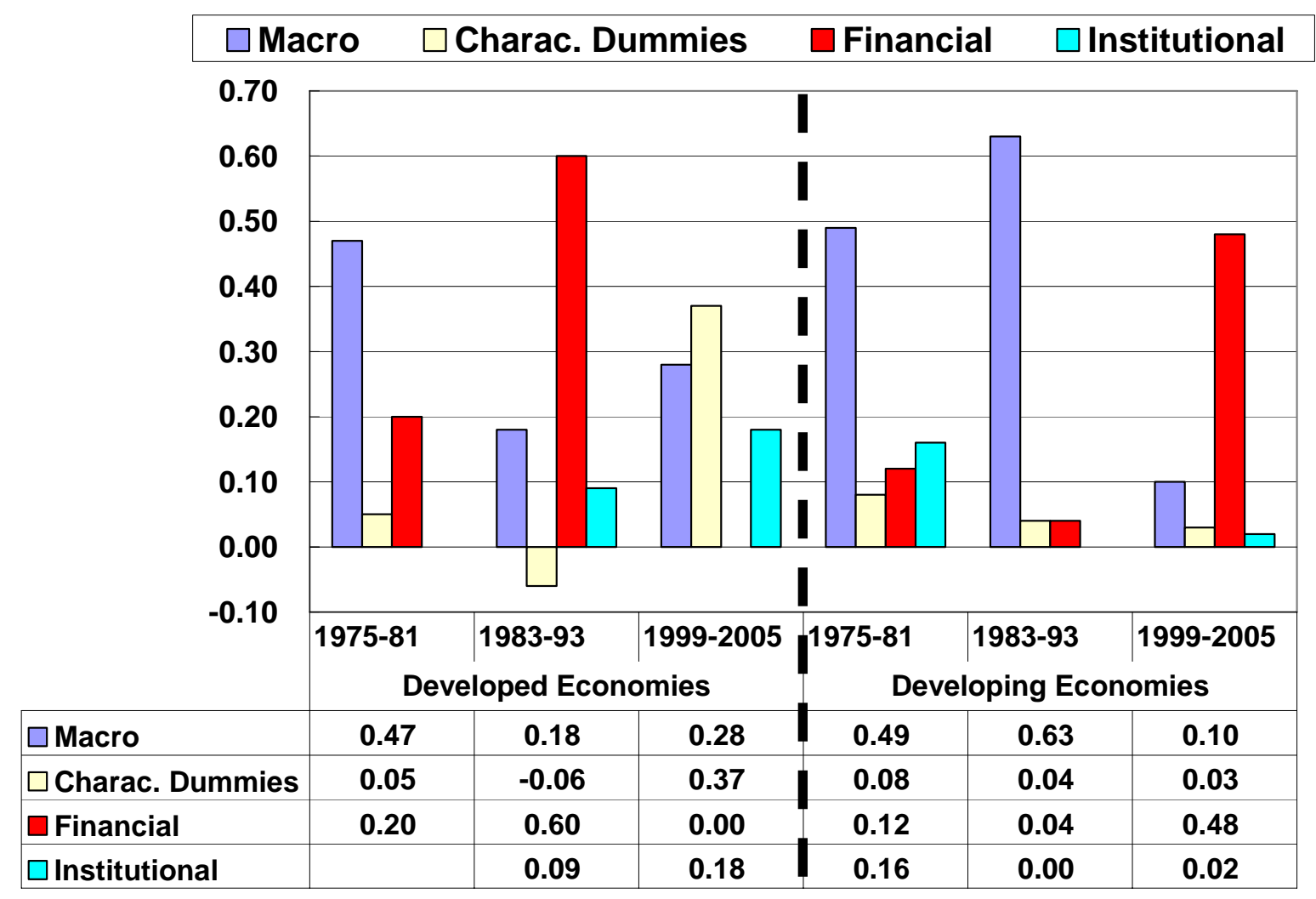

The explanatory power of these factors is not stable over time either. Figure 2 presents the incremental contributions of the four groups of explanatory variables implied by adjusted 
R-square estimates. That is, the bars in the figure show the incremental change in the adjusted R-square estimate when a group of explanatory variables is sequentially added to the estimation. A few observations stand out.

First, in the 30-year span, the group of macro variables displays the most significant drop in explanatory power. Its contributions to the adjusted R-square estimate fall from $47 \%$ in the $1975-1981$ period to $28 \%$ in the $1999-2005$ period for the developed economies and from $63 \%$ in the 1983 - 93 period to merely 10\% in the last period for the developing economies. The fact that the group of significant macro variables changes across periods makes it difficult to track the evolution of a variable's impact. Nonetheless, the results tend to support the notion that the propensity to import effect is declining over time.

Second, for the developing economies, the incremental explanatory power of the financial variables increases rapidly to the level of 48\% in the $1999-2005$ period. The result reflects the growing importance of capital and financial transactions amid the continuing financial liberalization and globalization for developing economies. The developed economies, on the other hand, see the incremental explanatory power of the financial variables reaches its top level of $60 \%$ in the $1983-1993$ period and then drops to zero after the Asian financial crisis. Thus, after the crisis, the financial factors are more relevant for a developing economy's demand for international reserves than for a developed economy. Apparently, for both groups of economies, the importance of financial variables is growing at the expense of the group of macro variables.

Third, the results do not give a clear trend for the role of the characteristics dummies and institutional variables. In the case of the developed economies, the institutional factors appear to be gaining importance over the last two periods, whereas the opposite seems to hold for the developing economies. In general, the role of institutional factors is minimal.

The role of financial and institutional factors deserves some comments. Until recently, the literature has not paid much attention to the implications of financial and institutional factors. Nevertheless, the effects of these two types of factors are found in the 1970s and 1980s samples. Our results, however, should not be interpreted as strong evidence of the effect of a specific financial or institutional factor. Indeed, we do not find a variable that shows up consistently in all three periods under investigation. The effects of the significant financial and institutional variables vary quite substantially across specifications. For example, the M2 effect is detected for 
developed economies in the first two sample periods but is only found for developing economies in the most recent period.

\subsubsection{Parameter Stability}

The variability of model specifications and coefficient estimates across sample periods and economy groups is quite transparent in Tables 1-1 and 1-2. To verify it formally, we examine parameter stability using the Wald test. Specifically, we pool the data from two sample periods, include variables that are significant in either one of the periods, and test whether the parameters are constant over the combined sample period. The period pairs considered are 1975 - 1981 vs. 1983 - 1993, 1975 - 1981 vs. 1999-2005, and 1983 - 1993 vs. 1999-2005. The procedure is applied to both the developed and developing economies. Also, we test the parameter stability for each of the four groups of explanatory variables.

The Wald test results confirm that the coefficient estimates are significantly different across any two sample periods. ${ }^{24}$ The evidence lends support to the view that economies alter their international reserve holding behaviors before and after major global financial disturbances.

One potential issue with our choice of the sample periods is that there is a five-year gap between the 1983-1993 and 1999-2005 samples. With the current setting, it is not clear whether it is the 1994 Tequila crisis or the 1997-98 Asian financial crisis that causes the change in the international reserve hoarding behavior in the 1990s. To further investigate the underlying reason of coefficient instability, we test parameter constancy over the two periods 1983-1993 and 1995-2005 that are separated by the 1994 Tequila crisis, as well as that over the 1983-1996 and 1999-2005 periods separated by the Asian financial crisis.

The Wald test results show that, for both developed and developing economies, the coefficient estimates are significantly different before and after both the Tequila and Asian financial crises. These findings corroborate our choice of the three sample periods.

\section{Additional Analyses}

\subsection{Does it Matter if an Economy Is a Developed or Developing One?}

What would happen if a developed economy accumulates international reserves as if it were a developing economy, or vice versa? Let the estimated demand for international reserves

24 For brevity, the Wald test results are not reported here, but are available from the authors. 
of developing economies be

$$
r_{i, d p}=\hat{\mathrm{c}}_{d p}+W_{i, d p}{ }^{\prime} \hat{\alpha}_{d p}+\hat{\varepsilon}_{i, d p} \equiv \hat{r}_{i, d p}+\hat{\varepsilon}_{i, d p},
$$

and that of developed economies be

$$
r_{i, d d}=\hat{\mathrm{c}}_{d d}+W_{i, d d}{ }^{\prime} \hat{\alpha}_{d d}+\hat{\varepsilon}_{i, d d} \equiv \hat{r}_{i, d d}+\hat{\varepsilon}_{i, d d},
$$

where “^” indicates a parameter estimate; the subscripts “ $d p$ ” and " $d d$ ” denote developing and developed economies; $W_{i, d p}$ contains the significant factors; $\hat{\alpha}_{d p}$ is the vector containing the corresponding estimates; and $\hat{r}_{i, d p}$ is the predicted level of international reserves. $W_{i, d d}, \hat{\alpha}_{d d}$, and $\hat{r}_{i, d d}$ are similarly defined.

Suppose a developed economy behaves like a developing economy, what would be its predicted level of international reserves? One way to address this question is to generate the “predicted” level of international reserves for this economy by applying its data to equation (5), which is estimated from the data of developing economies. We label this predicted value $\tilde{r}_{i, d d}$. By comparing $\hat{r}_{i, d d}$ with $\tilde{r}_{i, d d}$, one can assess the value (or cost) of being labeled as a developed economy. Similarly, we can generate $\tilde{r}_{i, d p}$ for a developing economy using equation (6) and data from the developing economies. Again, we can infer from $\hat{r}_{i, d p}$ and $\tilde{r}_{i, d p}$ the implications of a developing economy label.

First, we consider the case of a developing economy that behaves like a developed economy and generate $\tilde{r}_{i, d p}$ and $\hat{r}_{i, d p}$ for all four regression specifications (1) to (4). For brevity, the discussion in this and the following subsection are based on results pertaining to specification (4), which includes all four types of explanatory variables. Subsample averages are used in place of missing values.

Figure 3 presents three values of international reserves (as a ratio to GDP) for each economy: actual levels of international reserves $\left(r_{i, d p}\right)$; predicted values from the fitted equation for the developing economies sample $\left(\hat{r}_{i, d p}\right)$ - which we call the "simple" predictions for simplicity; and predicted values from the fitted equation for the developed economies $\left(\tilde{r}_{i, d p}\right)-$ which we call the "cross” predictions. In the figure, the economies are sorted in descending order (from the left to the right) according to their real per capita GDP in U.S. dollars.

As expected, the simple predictions $\left(\hat{r}_{i, d p}\right)$ match the actual values of international 
reserves $\left(r_{i, d p}\right)$ quite well. The distribution of the cross predictions $\left(\tilde{r}_{i, d p}\right)$, on the other hand, depends on the sample period.

Figure 3: Developing Economies Behave as if They were Developed Economies

A: $1975-1981$

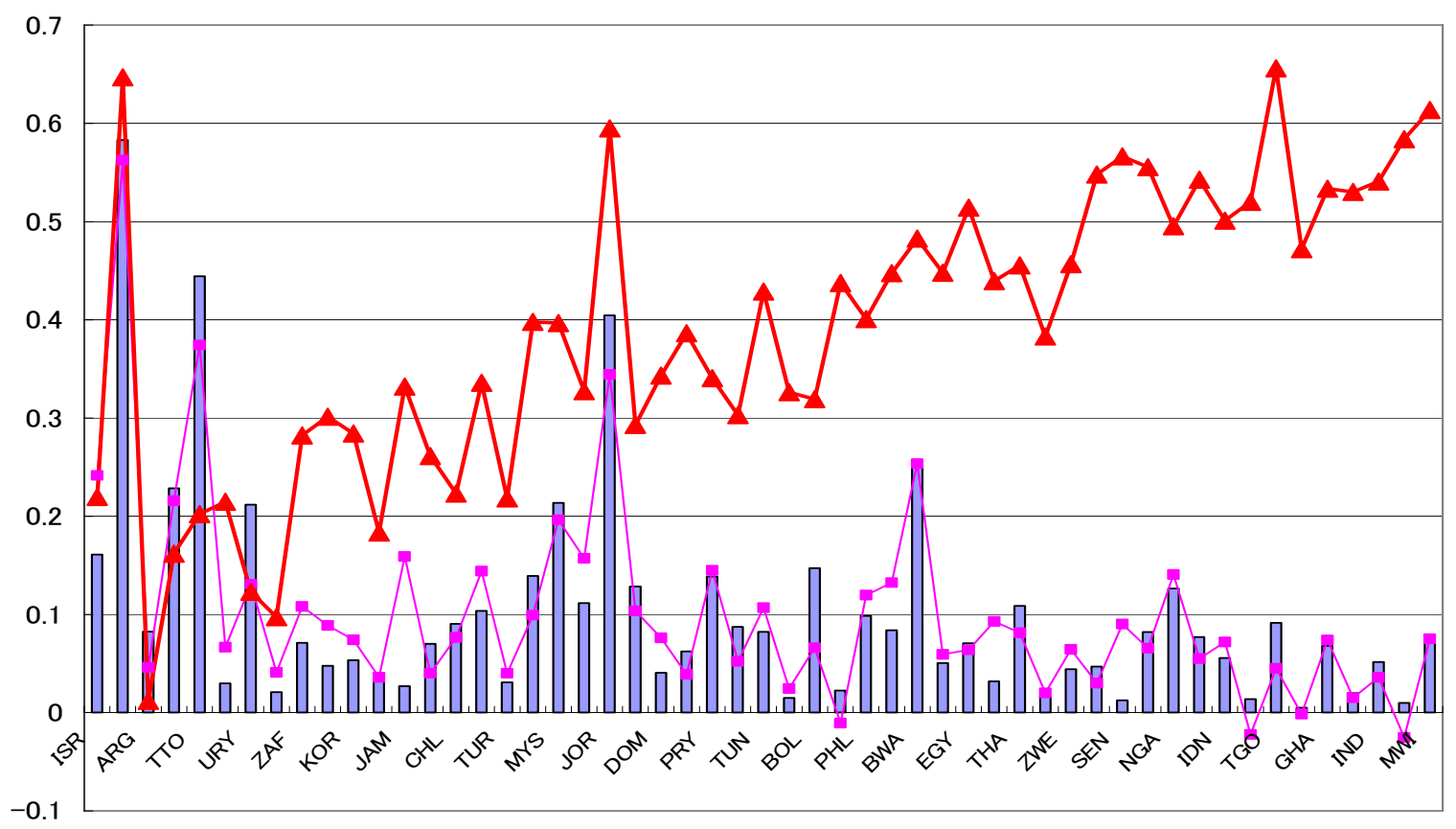

B: $1983-1993$

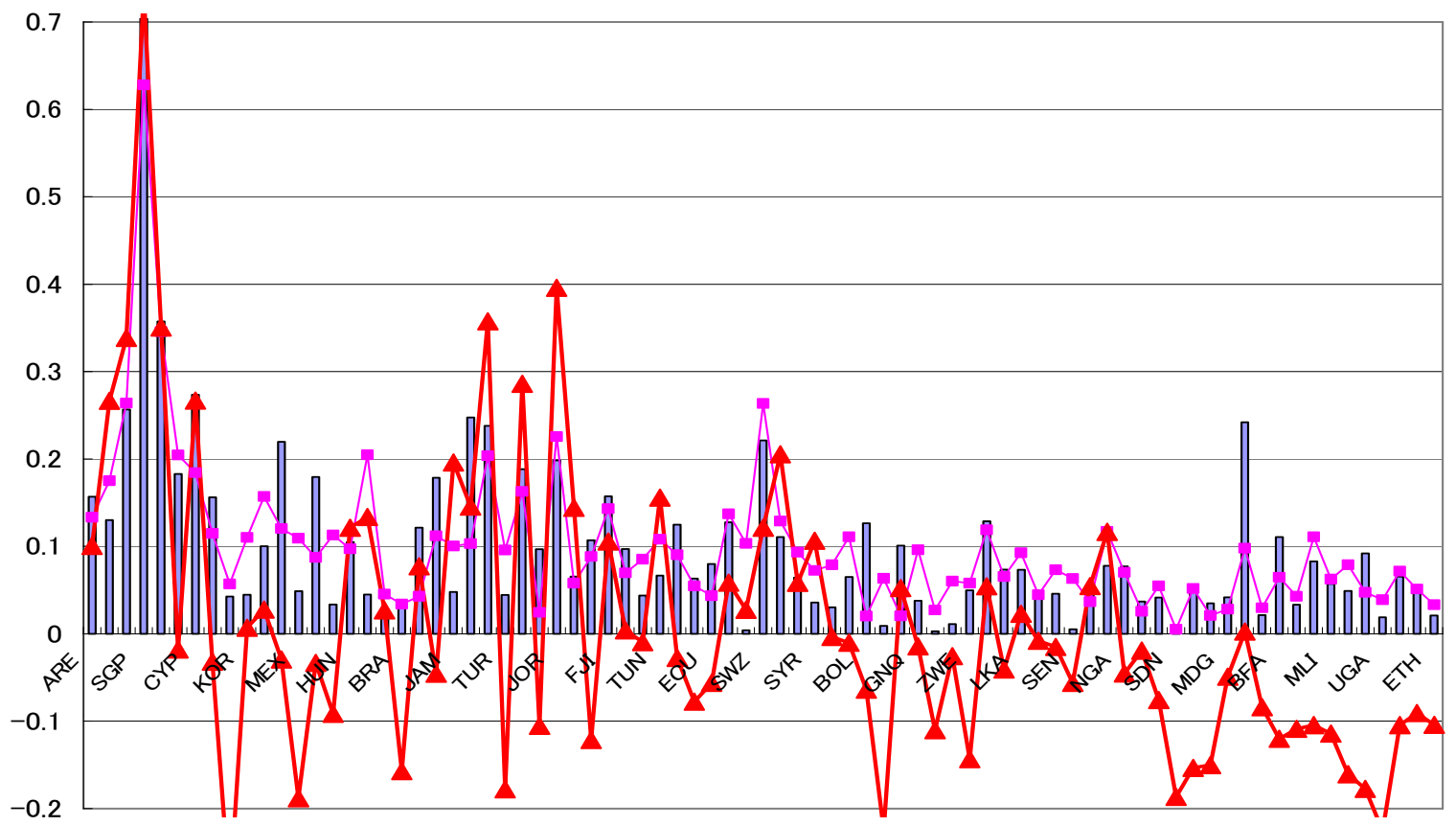


C: 1999-2005

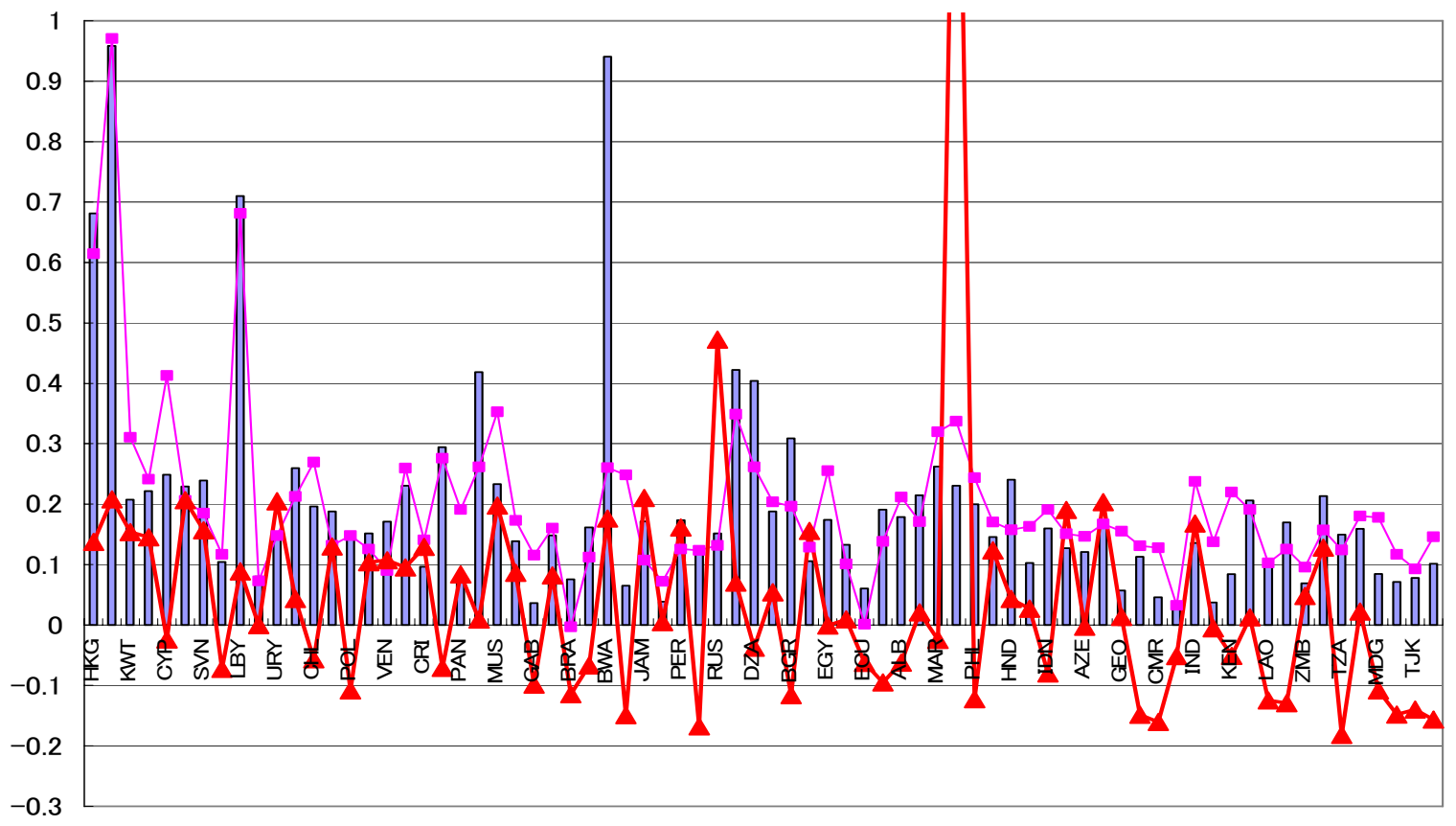

Actual levels of international reserves

- Simple predicted values from the models of developing economies

- Cross predicted values from the models of developed economies

In the 1975 - 1981 sample (Panel A), the cross prediction values $\left(\tilde{r}_{i, d p}\right)$ appear consistently above the simple prediction values $\left(\hat{r}_{i, d p}\right)$. Also, the gap between $\hat{r}_{i, d p}$ and $\tilde{r}_{i, d p}$ diverges as the level of real per capita income declines. Based on the estimation results in Tables 1-1 and 1-2, we can conjecture that the observed divergence is driven by the negative real output (per capita) effect found for developed economies in this period. The negative income effect may reflect the unfavorable conditions faced by low income economies in the international financial market in the 1970s. Thus, if developing economies were viewed as developed economies in the late 1970s, these economies, especially those with low per capita income, would have been required to hold higher levels of international reserves.

For the 1983 - 1993 and 1999-2005 periods, the cross predictions $\left(\tilde{r}_{i, d p}\right)$ are quite often lower than the corresponding simple predictions $\left(\hat{r}_{i, d p}\right)$. During these two sample periods, if developing economies could behave as developed ones, they would hold lower levels of international reserves. That is, compared with developed economies with similar economic and 
financial conditions, developing economies tend to hold more international reserves. The result suggests that there are some "intrinsic" differences between developed and developing economies that are not captured by the explanatory variables considered in the current exercise. These uncaptured features may include differences in their accessibilities to international financial markets and vulnerabilities to crises. Unfortunately, we do not have variables to account for these differences.

Admittedly, it is quite difficult to decipher the numerical values of international reserves from Figure 3. Table 2 reports the actual values and the two types of predicted values of international reserves for some Asian economies, the ones that are often perceived to hold an excessive amount of international reserves, as well as some selected subgroups. In Table 2, positive values in column (3) mean that a developing economy has a level of international reserves higher than the simple predicted value $\left(r_{i, d p}-\hat{r}_{i, d p}>0\right)$ whereas those in column (5) mean that the economy has a level of international reserves higher than the one implied by cross prediction $\left(r_{i, d p}-\tilde{r}_{i, d p}>0\right)$. Column (6) reports the differences between the two predicted values, $\hat{r}_{i, d p}-\tilde{r}_{i, d p}$. In general, Table 2 confirms the observations we made with Figure 3.

It is worthwhile noting that the relative magnitudes of the differences in the two types of predicted values of international reserves vary across sample periods. For example, during the 1983 - 1993 period, the Latin America group gives the largest difference between the two predicted values (column (6)) while the emerging Asian group yields the smallest. However, during the 1999-2005 period, the opposite is true for the two groups.

Furthermore, the discrepancies between the two kinds of predictions vary substantially across the economies. In the 1999-2005 sample, the actual levels of international reserves held by Hong Kong, Malaysia, Singapore, and Thailand are much higher than the cross predictions. Singapore is an extreme case - the economy's actual level of international reserves is slightly lower than the simple predicted value, but is higher than the cross prediction by $75.0 \%$ ! Thus, if the criteria of the developed economies are used to assess adequacy, these developing economies would be deemed to have an excessive level of international reserves.

Another interesting case is China. During the 1999-2005 sample period, China's holding of international reserves is $10.7 \%$ lower than the simple predicted value. The degree of deficiency increases to $144.7 \%$ when the cross prediction is used as a reference point! That is, 
Table 2: Developing Economies Behave as if They were Developed Economies

\begin{tabular}{|c|c|c|c|c|c|c|}
\hline & Actual & $\begin{array}{l}\text { Estimates based on } \\
\text { developing economy } \\
\text { equations, } \hat{r}_{i, d p}\end{array}$ & $\begin{array}{l}\text { Errors } \\
(1)-(2)\end{array}$ & $\begin{array}{l}\text { Estimates based } \\
\text { on developed } \\
\text { economy } \\
\text { equations, } \tilde{r}_{i, d p}\end{array}$ & $\begin{array}{l}\text { Errors } \\
\text { (1) - (4) }\end{array}$ & $\begin{array}{c}\text { Differences } \\
\text { (2) - (4) }\end{array}$ \\
\hline & (1) & (2) & (3) & (4) & (5) & (6) \\
\hline \multicolumn{7}{|l|}{ 1. $1975-1981$} \\
\hline Indonesia & $5.6 \%$ & $7.2 \%$ & $-1.6 \%$ & $50.1 \%$ & $-44.5 \%$ & $-42.9 \%$ \\
\hline Korea & $5.3 \%$ & $7.4 \%$ & $-2.1 \%$ & $28.4 \%$ & $-23.1 \%$ & $-21.0 \%$ \\
\hline Malaysia & $21.3 \%$ & $19.6 \%$ & $1.7 \%$ & $39.7 \%$ & $-18.3 \%$ & $-20.0 \%$ \\
\hline Philippines & $9.8 \%$ & $12.0 \%$ & $-2.1 \%$ & $40.1 \%$ & $-30.2 \%$ & $-28.1 \%$ \\
\hline Singapore & $58.3 \%$ & $56.2 \%$ & $2.1 \%$ & $64.7 \%$ & $-6.4 \%$ & $-8.5 \%$ \\
\hline Thailand & $10.9 \%$ & $8.1 \%$ & $2.8 \%$ & $45.5 \%$ & $-34.7 \%$ & $-37.4 \%$ \\
\hline The whole group & $8.0 \%$ & $9.4 \%$ & $-1.4 \%$ & $29.3 \%$ & $-21.3 \%$ & $-19.9 \%$ \\
\hline Emerging Asia & $10.7 \%$ & $11.5 \%$ & $-0.8 \%$ & $42.2 \%$ & $-31.4 \%$ & $-30.7 \%$ \\
\hline Latin America & $7.7 \%$ & $7.0 \%$ & $0.7 \%$ & $14.4 \%$ & $-6.8 \%$ & $-7.4 \%$ \\
\hline Oil Countries & $17.9 \%$ & $16.8 \%$ & $1.1 \%$ & $32.3 \%$ & $-14.4 \%$ & $-15.5 \%$ \\
\hline \multicolumn{7}{|l|}{ 2. 1983-1993 } \\
\hline China & $7.8 \%$ & $11.7 \%$ & $-3.9 \%$ & $11.7 \%$ & $-3.9 \%$ & $0.0 \%$ \\
\hline Indonesia & $7.3 \%$ & $6.5 \%$ & $0.8 \%$ & $-4.1 \%$ & $11.4 \%$ & $10.6 \%$ \\
\hline Korea & $4.5 \%$ & $11.0 \%$ & $-6.5 \%$ & $0.7 \%$ & $3.8 \%$ & $10.3 \%$ \\
\hline Malaysia & $23.8 \%$ & $20.4 \%$ & $3.4 \%$ & $35.7 \%$ & $-12.0 \%$ & $-15.4 \%$ \\
\hline Philippines & $6.5 \%$ & $11.1 \%$ & $-4.6 \%$ & $-1.0 \%$ & $7.5 \%$ & $12.1 \%$ \\
\hline Singapore & $70.9 \%$ & $62.8 \%$ & $8.1 \%$ & $73.4 \%$ & $-2.5 \%$ & $-10.6 \%$ \\
\hline Thailand & $12.8 \%$ & $13.7 \%$ & $-0.9 \%$ & $5.8 \%$ & $6.9 \%$ & $7.9 \%$ \\
\hline The whole group & $8.4 \%$ & $9.5 \%$ & $-1.0 \%$ & $-1.4 \%$ & $9.9 \%$ & $10.9 \%$ \\
\hline Emerging Asia & $12.2 \%$ & $14.4 \%$ & $-2.2 \%$ & $7.6 \%$ & $4.5 \%$ & $6.7 \%$ \\
\hline Latin America & $6.7 \%$ & $7.1 \%$ & $-0.4 \%$ & $-15.7 \%$ & $22.4 \%$ & $22.7 \%$ \\
\hline Oil Countries & $16.0 \%$ & $13.3 \%$ & $2.7 \%$ & $3.3 \%$ & $12.7 \%$ & $10.0 \%$ \\
\hline \multicolumn{7}{|l|}{ 3. 1999-2005 } \\
\hline China & $23.0 \%$ & $33.7 \%$ & $-10.7 \%$ & $167.8 \%$ & $-144.7 \%$ & $-134.0 \%$ \\
\hline Hong Kong & $68.1 \%$ & $61.5 \%$ & $6.7 \%$ & $13.8 \%$ & $54.4 \%$ & $47.7 \%$ \\
\hline Indonesia & $16.0 \%$ & $19.1 \%$ & $-3.1 \%$ & $-8.0 \%$ & $24.0 \%$ & $27.2 \%$ \\
\hline Korea & $22.9 \%$ & $20.6 \%$ & $2.3 \%$ & $20.7 \%$ & $2.3 \%$ & $0.0 \%$ \\
\hline Malaysia & $41.9 \%$ & $26.1 \%$ & $15.7 \%$ & $0.9 \%$ & $41.0 \%$ & $25.3 \%$ \\
\hline Philippines & $20.0 \%$ & $24.4 \%$ & $-4.4 \%$ & $-12.3 \%$ & $32.3 \%$ & $36.7 \%$ \\
\hline Singapore & $95.9 \%$ & $97.1 \%$ & $-1.2 \%$ & $20.8 \%$ & $75.0 \%$ & $76.3 \%$ \\
\hline Thailand & $29.2 \%$ & $30.2 \%$ & $-1.0 \%$ & $-9.0 \%$ & $38.1 \%$ & $39.1 \%$ \\
\hline The whole group & $20.0 \%$ & $22.0 \%$ & $-2.0 \%$ & $37.3 \%$ & $-17.3 \%$ & $-15.3 \%$ \\
\hline Emerging Asia & $34.9 \%$ & $32.8 \%$ & $2.1 \%$ & $9.4 \%$ & $25.6 \%$ & $23.4 \%$ \\
\hline Latin America & $9.8 \%$ & $7.2 \%$ & $2.6 \%$ & $-3.4 \%$ & $13.2 \%$ & $10.6 \%$ \\
\hline Oil Countries & $29.1 \%$ & $21.8 \%$ & $7.3 \%$ & $4.7 \%$ & $24.4 \%$ & $17.1 \%$ \\
\hline
\end{tabular}

NOTES: Due to data availability, China is not included in the 1975-81 sample, and Hong Kong is not in the 1975-81 and 1983-93 samples. The "Emerging Asia" group does not include China. The subsample average is a real US dollar GDP weighted average. Therefore, the prediction errors for "The whole group" in columns (3) are not necessarily zero. A positive (negative) error in columns (3) and (5) indicates over(under)-hoarding of international reserves relative to model predictions. 
both specifications for developing or developed economies suggest that China's holding of international reserves should have been higher between 1999 and 2005.

Next, we repeat the exercise for the group of developed economies and present the results in Figure 4 and Table 3. The panels in Figure 4 show that, generally, the simple prediction values are lower than the cross prediction ones; if a developed economy were treated as a developing economy, it would have to hold a higher level of international reserves - a result consistent with the previous analysis. Comparing the graphs from the three sample periods, the discrepancy between the two kinds of predicted values is the smallest during the second period.

Figure 4: Developed Economies Behave as if They were Developing Economies

A: $1975-81$

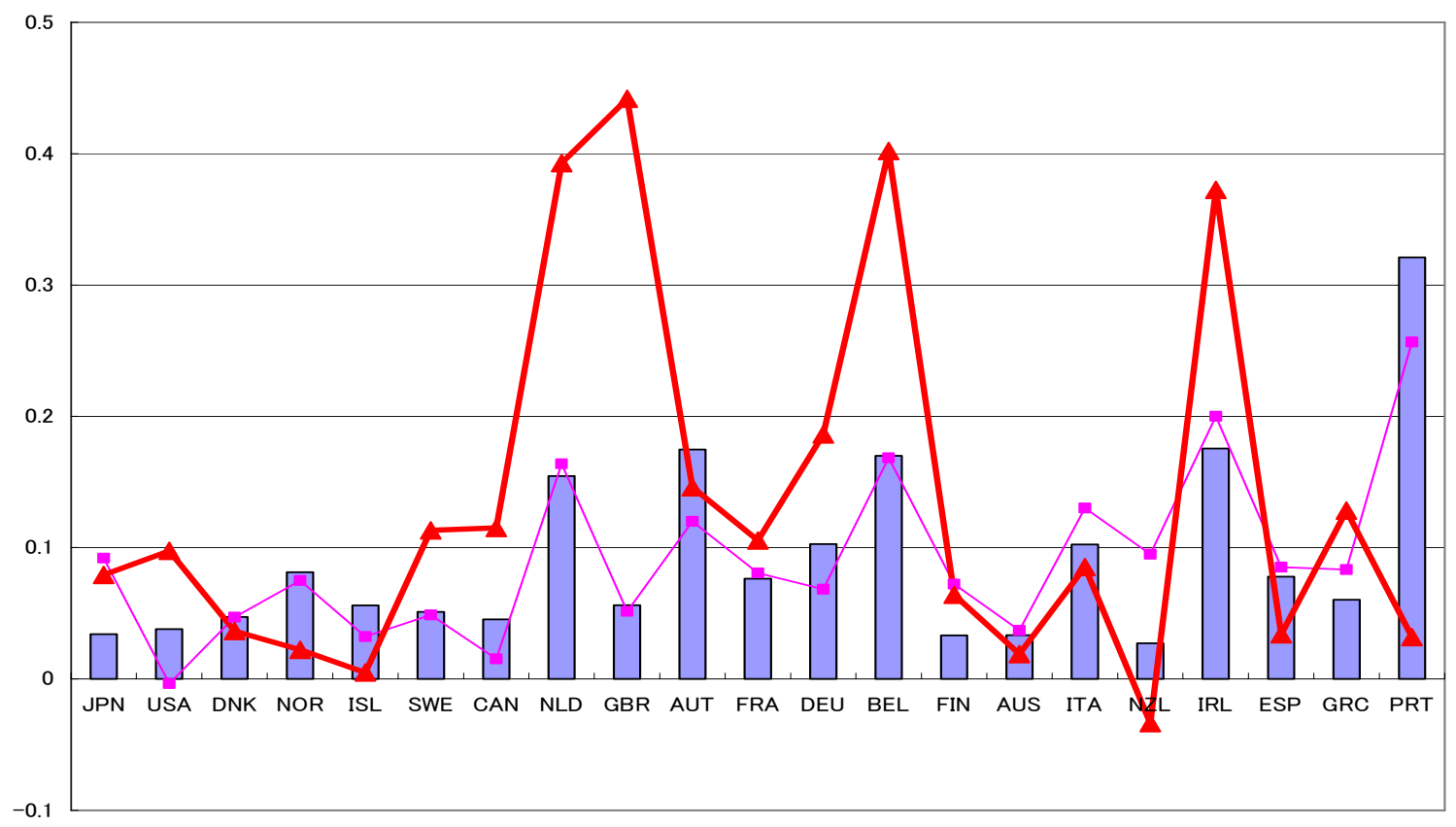


B: $1983-1993$

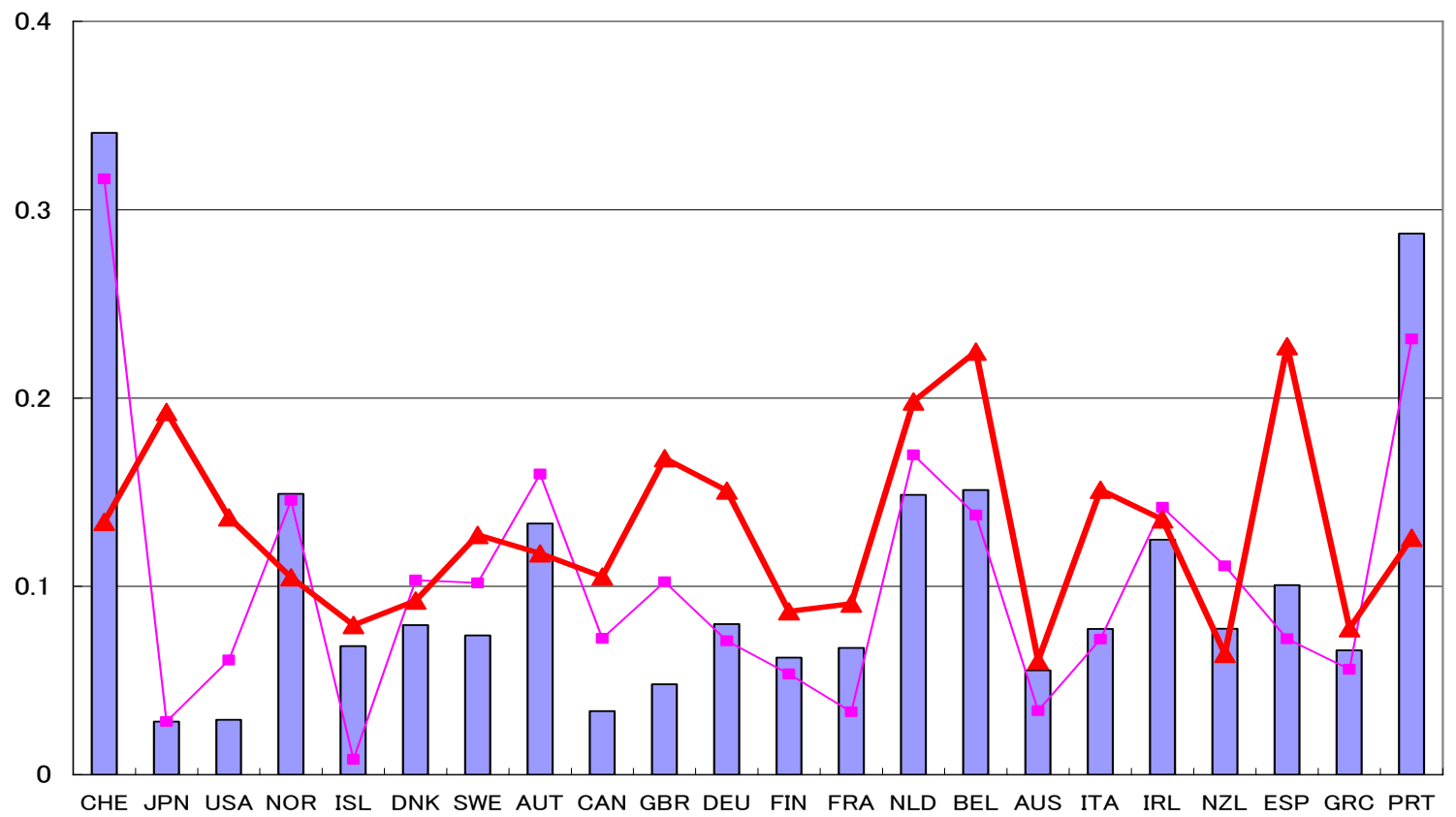

C: $1999-2005$

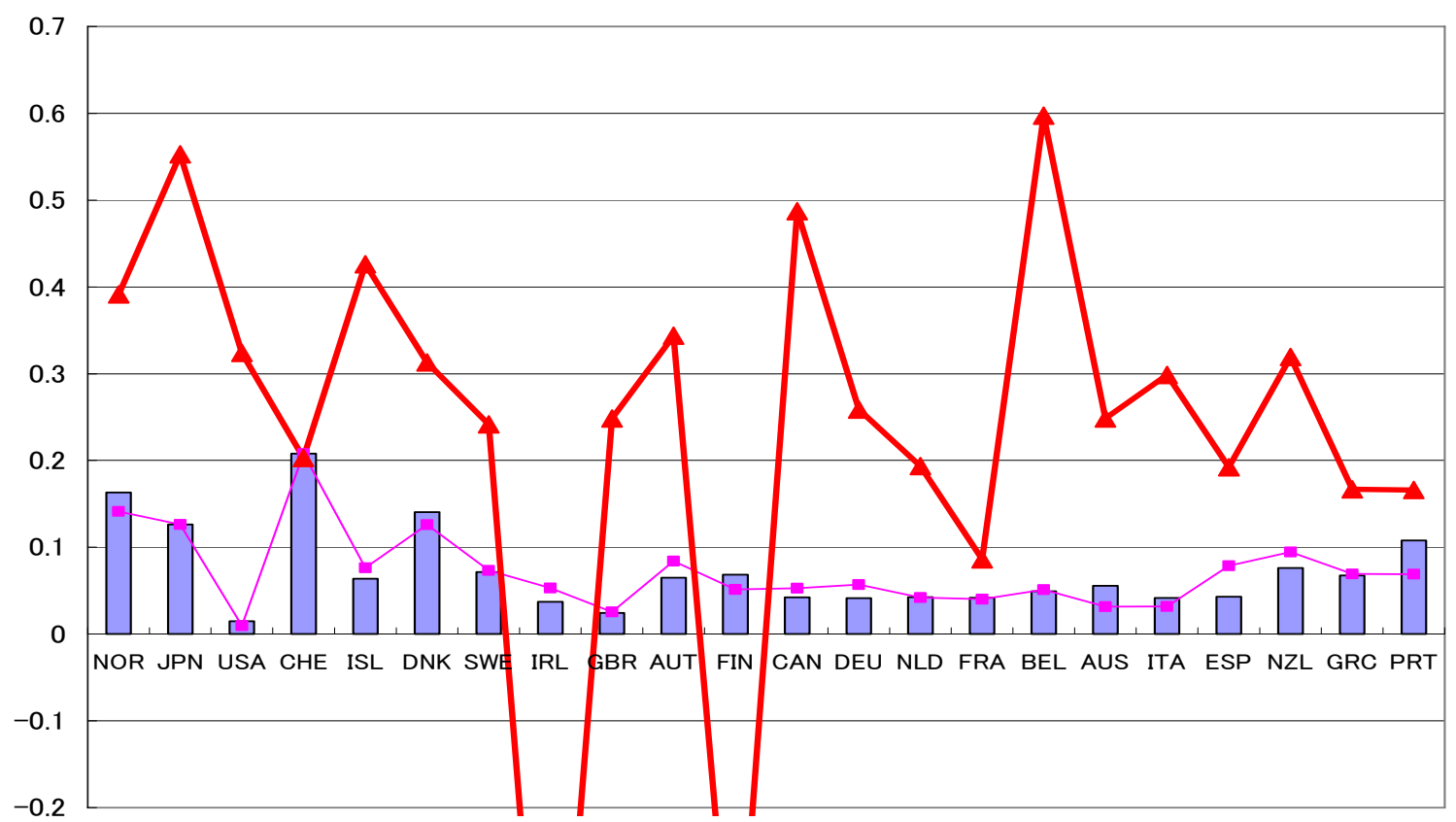

Actual level of international reserves

- Simple predicted values from the models of developed economies

$t-$ Cross predicted values from the models of developing economies 
Table 3 confirms that the group of developed economies holds a level of international reserves much lower than what is predicted by the fitted model for developing economies. Interestingly, Japan, one of the largest holders of international reserves, is deemed to have too few international reserves during the 1999-2005 period; its average level of international reserves is $12.6 \%$ (of its GDP), but the cross prediction indicates that the ratio should be $55.3 \%$.

Table 3: Developed Economies Behave as if they were Developing Economies

\begin{tabular}{|c|c|c|c|c|c|c|}
\hline & Actual & $\begin{array}{l}\text { Estimates based } \\
\text { on developed } \\
\text { economy } \\
\text { equations, } \hat{r}_{i, d d}\end{array}$ & $\begin{array}{l}\text { Errors } \\
(1)-(2)\end{array}$ & $\begin{array}{l}\text { Estimates based } \\
\text { on developing } \\
\text { economy } \\
\text { equations, } \widetilde{r}_{i, d d}\end{array}$ & $\begin{array}{l}\text { Errors } \\
(1)-(4)\end{array}$ & $\begin{array}{l}\text { Differences } \\
(2)-(4)\end{array}$ \\
\hline & (1) & (2) & (3) & (4) & (5) & (6) \\
\hline 1975 - 1981 & & & & & & \\
\hline U.K. & $5.6 \%$ & $5.1 \%$ & $0.5 \%$ & $44.2 \%$ & $-38.6 \%$ & $-39.0 \%$ \\
\hline Germany & $10.3 \%$ & $6.8 \%$ & $3.5 \%$ & $18.6 \%$ & $-8.3 \%$ & $-11.8 \%$ \\
\hline Japan & $3.4 \%$ & $9.2 \%$ & $-5.8 \%$ & $7.9 \%$ & $-4.5 \%$ & $1.3 \%$ \\
\hline $\begin{array}{l}\text { Average of developed } \\
\text { economies }\end{array}$ & $6.6 \%$ & $5.0 \%$ & $1.6 \%$ & $14.2 \%$ & $-7.6 \%$ & $-9.2 \%$ \\
\hline 2. $1983-1993$ & & & & & & \\
\hline U.K. & $4.8 \%$ & $10.2 \%$ & $-5.4 \%$ & $16.8 \%$ & $-12.0 \%$ & $-6.6 \%$ \\
\hline Germany & $8.0 \%$ & $7.1 \%$ & $0.9 \%$ & $15.1 \%$ & $-7.1 \%$ & $-8.0 \%$ \\
\hline Japan & $2.8 \%$ & $2.8 \%$ & $0.0 \%$ & $19.3 \%$ & $-16.4 \%$ & $-16.4 \%$ \\
\hline $\begin{array}{l}\text { Average of developed } \\
\text { economies }\end{array}$ & $5.4 \%$ & $6.6 \%$ & $-1.2 \%$ & $14.8 \%$ & $-9.4 \%$ & $-8.2 \%$ \\
\hline 3. $\quad 1999-2005$ & & & & & & \\
\hline U.K. & $2.5 \%$ & $2.6 \%$ & $-0.1 \%$ & $24.8 \%$ & $-22.4 \%$ & $-22.3 \%$ \\
\hline Germany & $4.1 \%$ & $5.7 \%$ & $-1.6 \%$ & $25.9 \%$ & $-21.7 \%$ & $-20.2 \%$ \\
\hline Japan & $12.6 \%$ & $12.6 \%$ & $0.0 \%$ & $55.3 \%$ & $-42.6 \%$ & $-42.6 \%$ \\
\hline $\begin{array}{l}\text { Average of developed } \\
\text { economies }\end{array}$ & $4.9 \%$ & $4.9 \%$ & $0.1 \%$ & $32.6 \%$ & $-27.7 \%$ & $-27.7 \%$ \\
\hline
\end{tabular}

NOTES: The average is a real US dollar GDP weighted average. Therefore, the prediction errors for “Average of developed economies” in columns (3) are not necessarily zero. A positive (negative) error in columns (3) and (5) indicates over- (under-) hoarding of international reserves relative to model predictions.

\subsection{Over- or Under-Hoarding of International Reserves?}

As we stated in the introduction, the recent phenomenal buildup of international reserves by some developing economies has triggered a contentious debate about whether these 
economies are holding an excessive amount of international reserves and, thus, posing a serious threat to the stability of the world economy. One traditional rule of thumb indicator of excessive international reserves holding is whether a country holds international reserves worth more than three months of imports. As of the end of 2006, the amount of international reserves held by China, Japan, Korea, Malaysia and Taiwan is worth 16.16, 18.22, 9.24, 5.00, and 15.75 months of imports, respectively, which is well above the three-month benchmark.

Our analysis, however, has shown that imports are just one of the determinants of the hoarding behavior. Furthermore, the importance of the propensity to import has been declining over years. Hence, the assessment of the adequacy of international reserves should go beyond the consideration of imports. There are additional complexities. For instance, our results in the previous section suggest that the holding pattern of international reserves has evolved over time. There is also evidence that, under similar conditions, developing economies tend to hold a level of international reserves higher than developed economies.

To shed more light on the issue of excessive hoarding in recent years, we generate the 1999-2005 predictions from the empirical equations of international reserves obtained in different sample periods. For example, the predicted values for developed economies are made by applying the 1999-2005 data to the fitted equations of developed economies in each of the three sample periods. The results are presented in Table 4. Columns (1) to (3) in the table are the same as the corresponding entries in columns (1) to (3) of Panel 3 in Tables 2 and 3 - they are included for comparison purposes. Columns (4) and (6) list the 1999-2005 predicted values generated from fitted models of the 1983-93 and the 1975-81 periods, respectively. Columns (5) and (7) are the prediction errors for columns (4) and (6), respectively.

When the 1999-2005 specifications are used, there is no substantial evidence of over-hoarding of international reserves. Among the selected Asian economies shown in Table 4, Malaysia has the highest level of over-hoarding - the excessive amount is more than one half of its predicted value. China, on the other hand, has the highest deficient rate of $10.7 \%$. Compared with developing economies, the developed economies display a lower degree of over-hoarding variability.

The use of the 1975 - 1981 and 1983 - 1993 models presents a different picture. In general, the actual holdings are lower than the values predicted by these two models. For developed economies, Japan is the only case that gives an over-hoarding result. Both the U.K. 
Table 4: Predicted Values of the 1999-2005 International reserves from Different Model Vintages

\begin{tabular}{|c|c|c|c|c|c|c|c|}
\hline & Actual & $\begin{array}{c}\text { Estimates based } \\
\text { on the 1999-05 } \\
\text { Model }\end{array}$ & $\begin{array}{l}\text { Errors } \\
\text { (1) - (2) }\end{array}$ & $\begin{array}{c}\text { Estimates based } \\
\text { on the 1983-93 } \\
\text { Model }\end{array}$ & $\begin{array}{l}\text { Errors } \\
\text { (1) - (4) }\end{array}$ & $\begin{array}{c}\text { Estimates based } \\
\text { on the 1975-81 } \\
\text { Model }\end{array}$ & $\begin{array}{l}\text { Errors } \\
(1)-(6)\end{array}$ \\
\hline & $(1)$ & $(2)$ & (3) & (4) & (5) & (6) & $(7)$ \\
\hline Developed Economies & & & & & & & \\
\hline U.K. & $2.5 \%$ & $2.6 \%$ & $-0.1 \%$ & $34.2 \%$ & $-31.8 \%$ & $10.3 \%$ & $-7.8 \%$ \\
\hline Germany & $4.1 \%$ & $5.7 \%$ & $-1.6 \%$ & $10.5 \%$ & $-6.4 \%$ & $6.2 \%$ & $-2.1 \%$ \\
\hline Japan & $12.6 \%$ & $12.6 \%$ & $0.0 \%$ & $7.8 \%$ & $4.8 \%$ & $12.1 \%$ & $0.5 \%$ \\
\hline Average of developed economies & $4.9 \%$ & $4.9 \%$ & $0.1 \%$ & $11.3 \%$ & $-6.4 \%$ & $3.5 \%$ & $1.4 \%$ \\
\hline 2. Developing Economies & & & & & & & \\
\hline China & $23.0 \%$ & $33.7 \%$ & $-10.7 \%$ & $201.5 \%$ & $-178.5 \%$ & $33.7 \%$ & $-10.7 \%$ \\
\hline Hong Kong & $68.1 \%$ & $61.5 \%$ & $6.7 \%$ & $59.1 \%$ & $9.1 \%$ & $398.7 \%$ & $-330.5 \%$ \\
\hline Indonesia & $16.0 \%$ & $19.1 \%$ & $-3.1 \%$ & $5.8 \%$ & $10.2 \%$ & $3.7 \%$ & $12.3 \%$ \\
\hline Korea & $22.9 \%$ & $20.6 \%$ & $2.3 \%$ & $49.7 \%$ & $-26.8 \%$ & $20.3 \%$ & $2.7 \%$ \\
\hline Malaysia & $41.9 \%$ & $26.1 \%$ & $15.7 \%$ & $46.2 \%$ & $-4.3 \%$ & $51.2 \%$ & $-9.3 \%$ \\
\hline Philippines & $20.0 \%$ & $24.4 \%$ & $-4.4 \%$ & $18.9 \%$ & $1.1 \%$ & $15.4 \%$ & $4.6 \%$ \\
\hline Singapore & $95.9 \%$ & $97.1 \%$ & $-1.2 \%$ & $57.2 \%$ & $38.6 \%$ & $273.9 \%$ & $-178.0 \%$ \\
\hline Thailand & $29.2 \%$ & $30.2 \%$ & $-1.0 \%$ & $23.5 \%$ & $5.7 \%$ & $24.7 \%$ & $4.5 \%$ \\
\hline Average of developing economies & $20.0 \%$ & $22.0 \%$ & $-2.0 \%$ & $60.9 \%$ & $-40.9 \%$ & $40.2 \%$ & $-20.2 \%$ \\
\hline Emerging Asia & $34.9 \%$ & $32.8 \%$ & $2.1 \%$ & $40.7 \%$ & $-5.8 \%$ & $87.2 \%$ & $-52.3 \%$ \\
\hline Latin America & $9.8 \%$ & $7.2 \%$ & $2.6 \%$ & $14.6 \%$ & $-4.8 \%$ & $23.6 \%$ & $-13.8 \%$ \\
\hline Oil Countries & $29.1 \%$ & $21.8 \%$ & $7.3 \%$ & $12.7 \%$ & $16.4 \%$ & $37.7 \%$ & $-8.6 \%$ \\
\hline
\end{tabular}

NOTES: The (subsample) averages real US dollar GDP weighted averages and thus are not necessarily zeros. A positive (negative) error in columns (3), (5), and (7) indicates over- (under-) hoarding of international reserves. The "Emerging Asia” group does not include China. 
and Germany are deemed to hold too few international reserves in the period. Indeed, Japan shows a relatively minor change in its estimated over- and under-hoarding positions.

The results for developing economies are quite striking. The predicted values show a high degree of variation. For instance, the 1983 - 1993 specification suggest Singapore holds the most “excessive” amount of international reserves (38.6\%) and China's level of international reserves is lower than the model prediction by a stunning 178.5\%. Under the 1975-1981 model, the Philippines over-hoards by 4.6\% while Hong Kong under-hoards by 330.5\%.

According to the 1983 - 1993 specification, the group of developing economies on average has a deficient amount of international reserves; the actual average holding is $6.4 \%$ less than the predicted value. The group of oil exporting economies has the highest level of excessive holding (16.4\%) among the subgroups.

The 1975 - 1981 specification gives an even more severe under-hoarding scenario. According to this vintage model, developing economies are under-hoarding on average by an amount of 52.3\%. All of the three geographical subgroups hold lower levels of international reserves than the model predictions. For individual economies, China, Hong Kong, and Singapore are the three economies that have the largest degrees of under-hoarding - for Hong Kong and Singapore, the size of international reserves holding is expected to be bigger than their GDPs!

In sum, the evidence for excessive holdings of international reserves in the 2000s is quite limited. Indeed, according to the models of the 1970s and 1980s, these selected economies tend to hold a deficient, instead of an excessive, amount of international reserves. These findings suggest that, in assessing the adequacy of international reserves, one has to take into account of both the changing global environment and the evolving role of international reserves.

\section{Concluding Remarks}

Against the backdrop of the astonishing growth of global international reserves and the recent advancements in modeling the demand for international reserves, we conduct an extensive cross-country analysis to examine the empirical determinants of international reserve holding. Four groups of determinants, namely, traditional macro variables, financial variables, institutional variables, and dummy variables that control for individual economy characteristics are considered. Also, accounting for the anecdotal evidence that major currency crises affect the 
demand for international reserves, we examined three sample periods partitioned by three major crisis episodes, the 1982 Mexican debt crisis, the 1994 Tequila crisis, and the 1997 Asian financial crisis.

It is found that the empirical specifications of the demand for international reserves differ between developed and developing economies and across the three sample periods. Indeed, the set of significant explanatory variables changes quite substantially across specifications. The propensity to import variable has the highest frequency of significant coefficient estimates but its effect appears to be declining over time. Formal Wald statistics confirm parameter non-constancy and corroborate our choice of sample periods. All in all, the empirical results highlight the difficulty of devising a single empirical model to describe the holding of international reserves. They also represent some challenges for building a unified theory of demand for international reserves.

Besides the changing nature of the estimated relationship, we find that the effects of financial and institutional factors are also significant contributors in the 1970s and 1980s even though only recently these factors are the subject of discussions. Our estimation results suggest that developing economies could hold lower levels of international reserves if they were to be perceived as developed ones. One interpretation is that, despite our relatively exhaustive list of explanatory variables, the fitted models do not fully capture the differences between these two groups of economies. Some possible omitted variables are market credibility and the level of sociopolitical governance. Unfortunately we do not have data on these variables.

Furthermore, our results do not lend strong support to the assertion that economies including China, Japan, and Korea are hoarding an excessive amount of international reserves in the 2000s. Specifically, the predicted values generated from various estimated equations of international reserves do not indicate a large over-hoarding phenomenon. Instead, the models of the 1975 - 1981 and 1983 - 1993 vintages suggest that these economies should have higher levels of international reserves than their actual holding levels in the 2000s. We do identify one condition under which some developing economies display signs of excessive hoarding in the 2000s - the use of models fitted to developed economies to generate the predicted level of international reserves.

The continuing process of globalization and the growing importance of capital account transactions are likely to be the reasons for the changing relationship between international 
reserves and their determinants. Understandably, the changing world economic environment makes the optimal level of international reserves a moving target. A corollary is that the assessment of the adequacy of international reserves is a non-trivial enterprise; especially in the periods that experience significant events in the international arena. Given the occurrence of dramatic events (both economic and geo-political ones) around the new millennium, it is reasonable to expect that the demand for international reserves will not be the same as it was in the past. Hence, the assertions of unusual or excessive hoarding of international reserves must be made with caution and be evaluated with the flexibility of allowing possible behavioral changes. 


\section{Appendix}

\section{Data Appendix}

Table A.1 presents the list of the variables considered in the exercise. Only variables that are found to be statistically significant are reported in the text. The table also provides the definitions of these variables and the sources of the primary data used to construct these variables. These are annual data from 1975 to 2005. The sample of economies consists of 22 developed economies and 104 developing economies.

\section{Period Averages of Some Selected Variables}

The period averages of the variables are reported in Table A.2. There are some obvious variations between developed and developing economies and across the three sample periods. While the two groups of economies have comparable levels of international reserves in the first two sample periods, there is a noticeable change in the 1999-2005 period. Since the Asian financial crisis, developing economies have accumulated a substantial amount of international reserves, averaging more than double that of developed economies.

A few other observations are in order. First, among the developed economies, macroeconomic variables usually remain relatively stable across the three periods. The developing economies, on the other hand, experience variations in some variables. For example, both volatilities of international reserve holdings and export receipts decline over time, a sharp contrast with the developed economies. The opportunity cost of holding international reserves peaks for the developing economies in the 1983-1993 period - reflecting the debt crisis in the period - and reverts back to a lower level in the last period, though still much higher compared to the developed economies.

Second, the financial variables exhibit some discernable differences between the two groups. The developed economies have a higher monetarization ratio, which is consistent with the perception that these economies have a higher degree of financial deepening and more advanced capital markets than the developing ones. The table shows that the group of developing economies is net receivers of external debt and FDI flows. ${ }^{25}$ Apparently, for developing economies, FDI flows are gaining importance recently while external debts peak in the 1983-1993 period.

Third, by eyeballing institutional variables, we can confirm that developed economies have already achieved high levels of institutional development and democracy in early years. Developing

\footnotetext{
25 Positive (Negative) net external financial liabilities correspond to net receivers (provider) of external finances.
} 
economies are on the catch-up trend, but still lagging behind the developed economies. It is worthwhile noting that the Chinn-Ito $(2006,2008)$ de jure index of financial openness suggests that countries have taken different paths of financial liberalization; the developed economies have constantly implemented financial liberalization since the 1970s while the developing economies restricted cross-border capital flows during the 1980s, though they rapidly reopened capital accounts after the mid-1990s (see Chinn and Ito, 2008). 
Table A.1: $\quad$ Definitions and Sources

\begin{tabular}{|c|c|c|}
\hline Variables & Definitions & Sources \\
\hline \multicolumn{3}{|l|}{ 1. Dependent variables } \\
\hline R_GDP & total international reserves (including gold)/current GDP & WDI \\
\hline \multicolumn{3}{|c|}{ 2. Variables in " $X "$ - "Macro variables" } \\
\hline RYPC_US & per capita GDP in constant US dollars & WDI \\
\hline POP & population & WDI \\
\hline PIMP & propensity to import & IFS \\
\hline RES_VOL & international reserve volatility & IFS \\
\hline DIFINT & opportunity cost of holding international reserves & WDI, IFS \\
\hline \multicolumn{3}{|c|}{ 3. Variables in "Y” - "Financial variables" } \\
\hline M2Y & M2 to current GDP & WDI, IFS \\
\hline NET_DEBT & net debt liabilities / current GDP & LM \\
\hline NET_FDI & net FDI liabilities / current GDP & $\mathrm{LM}$ \\
\hline NET_PORTFOLIO & net portfolio equity liabilities / current GDP & LM \\
\hline D_DEBT_LIAB & growth rate of net debt liabilities / current GDP & LM \\
\hline D_FDI_LIAB & growth rate of net FDI liabilities / current GDP & $\mathrm{LM}$ \\
\hline D_PORTFOLIO_LIAB & growth rate of net portfolio liabilities / current GDP & $\mathrm{LM}$ \\
\hline \multicolumn{3}{|c|}{ 4. Variables in "Z” - "Institutional variables" } \\
\hline KAOPEN & capital account openness & Chinn-Ito (2006) \\
\hline DEFACTO_FININT & $\begin{array}{l}\text { de facto financial openness } \\
=(\text { Total external assets + liabilities) / current GDP }\end{array}$ & LM \\
\hline TRADEOPEN & de jure trade openness & WDI \\
\hline CORRUPT & corruption $[0,6]$ & ICRG \\
\hline BQ & bureaucratic quality $[0,6]$ & ICRG \\
\hline LAO & law and Order $[0,6]$ & ICRG \\
\hline LEFT & dummy variable for left-wing government & DPI2004 \\
\hline PLURAL & dummy variable for parliament with Plural electoral system & DPI2004 \\
\hline GOVFRAC & government fractionalization $[0,1]$ & DPI2004 \\
\hline POLCONV & political constraint (democracy) index & Henisz (2000) \\
\hline \multicolumn{3}{|l|}{ 5. Dummies (“ $D ”)$} \\
\hline ER_CRAWL & dummy variable for the crawling peg exchange rate regime & $\mathrm{RR}$ \\
\hline ER_FIX & dummy variable for the fixed exchange rate regime & $\mathrm{RR}$ \\
\hline CRISIS & dummy variable for a currency crisis & Authors' calculations \\
\hline BANKCRISIS & dummy variable for a banking crisis & $\mathrm{CK}$ \\
\hline OIL & dummy variable for oil exporting countries & Authors' calculations \\
\hline
\end{tabular}

NOTES: The source codes are: BDL: Beck, Demirgüc-Kunt, and Levine (2000, updated in later years); CI: Chinn and Ito (2006); CK: Caprio and Klingebiel (2003); DPI2004: Database of Political Institutions, Beck et al. (2001); Henisz: Henisz (2000); ICRG: International Country Risk Guide; IFS: IMF's International Financial Statistics; IMF: Other IMF databases; LM: Lane and Milesi-Ferretti (2006); Polity IV: Polity IV project (2004); RR: Reinhart and Rogoff (2002, updated up to 2004); and WDI: World Development Indicators. 
Roubini, Nouriel, and Jeffrey Sachs, (1989), “Government Spending and Budget Deficits in the Industrial Countries,” Economic Policy, 8, 99-132.

Willett, Thomas D., (2003), "Fear of Floating Need Not Imply Fixed Exchange Rates,” Open Economies Review, 14, 77 - 91 

2609 Adam S. Booij, Bernard M.S. van Praag and Gijs van de Kuilen, A Parametric Analysis of Prospect Theory's Functionals for the General Population, April 2009

2610 Jeffrey R. Brown, Julia Lynn Coronado and Don Fullerton, Is Social Security Part of the Social Safety Net?, April 2009

2611 Ali Bayar and Bram Smeets, Economic, Political and Institutional Determinants of Budget Deficits in the European Union, April 2009

2612 Balázs Égert, The Impact of Monetary and Commodity Fundamentals, Macro News and Central Bank Communication on the Exchange Rate: Evidence from South Africa, April 2009

2613 Michael Melvin, Christian Saborowski, Michael Sager and Mark P. Taylor, Bank of England Interest Rate Announcements and the Foreign Exchange Market, April 2009

2614 Marie-Louise Leroux, Pierre Pestieau and Gregory Ponthiere, Should we Subsidize Longevity?, April 2009

2615 Ronald MacDonald, Lukas Menkhoff and Rafael R. Rebitzky, Exchange Rate Forecasters' Performance: Evidence of Skill?, April 2009

2616 Frederick van der Ploeg and Steven Poelhekke, The Volatility Curse: Revisiting the Paradox of Plenty, April 2009

2617 Axel Dreher, Peter Nunnenkamp, Hannes Öhler and Johannes Weisser, Acting Autonomously or Mimicking the State and Peers? A Panel Tobit Analysis of Financial Dependence and Aid Allocation by Swiss NGOs, April 2009

2618 Guglielmo Maria Caporale, Roman Matousek and Chris Stewart, Rating Assignments: Lessons from International Banks, April 2009

2619 Paul Belleflamme and Martin Peitz, Asymmetric Information and Overinvestment in Quality, April 2009

2620 Thomas Dohmen, Armin Falk, David Huffman and Uwe Sunde, Are Risk Aversion and Impatience Related to Cognitive Ability?, April 2009

2621 Yin-Wong Cheung and Xingwang Qian, The Empirics of China's Outward Direct Investment, April 2009

2622 Frédérique Bec and Christian Gollier, Assets Returns Volatility and Investment Horizon: The French Case, April 2009

2623 Ronnie Schöb and Marcel Thum, Asymmetric Information Renders Minimum Wages Less Harmful, April 2009

2624 Martin Ruf and Alfons J. Weichenrieder, The Taxation of Passive Foreign Investment Lessons from German Experience, April 2009 
2625 Yao Li, Borders and Distance in Knowledge Spillovers: Dying over Time or Dying with Age? - Evidence from Patent Citations, April 2009

2626 Jim Malley and Ulrich Woitek, Technology Shocks and Aggregate Fluctuations in an Estimated Hybrid RBC Model, April 2009

2627 Jin Cao and Gerhard Illing, Endogenous Systemic Liquidity Risk, April 2009

2628 Thiess Buettner and Bjoern Kauder, Revenue Forecasting Practices: Differences across Countries and Consequences for Forecasting Performance, April 2009

2629 Håkan Selin, The Rise in Female Employment and the Role of Tax Incentives - An Empirical Analysis of the Swedish Individual Tax Reform of 1971, April 2009

2630 Nick Johnstone and Ivan Hascic, Environmental Policy Design and the Fragmentation of International Markets for Innovation, April 2009

2631 Spiros Bougheas, Richard Kneller and Raymond Riezman, Optimal Education Policies and Comparative Advantage, April 2009

2632 Jay Pil Choi and Heiko Gerlach, Multi-Market Collusion with Demand Linkages and Antitrust Enforcement, April 2009

2633 Thor O. Thoresen, Income Mobility of Owners of Small Businesses when Boundaries between Occupations are Vague, April 2009

2634 Guido Schwerdt and Amelie C. Wuppermann, Is Traditional Teaching really all that Bad? A Within-Student Between-Subject Approach, April 2009

2635 Kurt R. Brekke, Luigi Siciliani and Odd Rune Straume, Hospital Competition and Quality with Regulated Prices, April 2009

2636 Peter Diamond, Taxes and Pensions, April 2009

2637 Shoshana Grossbard, How "Chicagoan” are Gary Becker's Economic Models of Marriage?, May 2009

2638 Roland Strausz, Regulatory Risk under Optimal Incentive Regulation, May 2009

2639 Holger Zemanek, Ansgar Belke and Gunther Schnabl, Current Account Imbalances and Structural Adjustment in the Euro Area: How to Rebalance Competitiveness, May 2009

2640 Harald Hau and Marcel Thum, Subprime Crisis and Board (In-)Competence: Private vs. Public Banks in Germany, May 2009

2641 Martin Halla, Mario Lackner and Friedrich G. Schneider, An Empirical Analysis of the Dynamics of the Welfare State: The Case of Benefit Morale, May 2009

2642 Balázs Égert, Infrastructure Investment in Network Industries: The Role of Incentive Regulation and Regulatory Independence, May 2009 
2643 Christian Gollier, Expected Net Present Value, Expected Net Future Value, and the Ramsey Rule, May 2009

2644 Sören Blomquist and Håkan Selin, Hourly Wage Rate and Taxable Labor Income Responsiveness to Changes in Marginal Tax Rates, May 2009

2645 Dominique Demougin, Oliver Fabel and Christian Thomann, Implicit vs. Explicit Incentives: Theory and a Case Study, May 2009

2646 Francesco C. Billari and Vincenzo Galasso, What Explains Fertility? Evidence from Italian Pension Reforms, May 2009

2647 Kjell Arne Brekke, Karen Evelyn Hauge, Jo Thori Lind and Karine Nyborg, Playing with the Good Guys - A Public Good Game with Endogenous Group Formation, May 2009

2648 Guglielmo Maria Caporale and Luis A. Gil-Alana, Multi-Factor Gegenbauer Processes and European Inflation Rates, May 2009

2649 Henning Bohn, A Static Model for Voting on Social Security, May 2009

2650 Markus Haavio and Kaisa Kotakorpi, The Political Economy of Sin Taxes, May 2009

2651 Augusto de la Torre, María Soledad Martínez Pería and Sergio L. Schmukler, Drivers and Obstacles to Banking SMEs: The Role of Competition and the Institutional Framework, May 2009

2652 Tobias Lindhe and Jan Södersten, Dividend Taxation, Share Repurchases and the Equity Trap, May 2009

2653 Assaf Razin and Edith Sand, Migration-Regime Liberalization and Social Security: Political-Economy Effect, May 2009

2654 Yin-Wong Cheung and Hiro Ito, A Cross-Country Empirical Analysis of International Reserves, May 2009 
2643 Christian Gollier, Expected Net Present Value, Expected Net Future Value, and the Ramsey Rule, May 2009

2644 Sören Blomquist and Håkan Selin, Hourly Wage Rate and Taxable Labor Income Responsiveness to Changes in Marginal Tax Rates, May 2009

2645 Dominique Demougin, Oliver Fabel and Christian Thomann, Implicit vs. Explicit Incentives: Theory and a Case Study, May 2009

2646 Francesco C. Billari and Vincenzo Galasso, What Explains Fertility? Evidence from Italian Pension Reforms, May 2009

2647 Kjell Arne Brekke, Karen Evelyn Hauge, Jo Thori Lind and Karine Nyborg, Playing with the Good Guys - A Public Good Game with Endogenous Group Formation, May 2009

2648 Guglielmo Maria Caporale and Luis A. Gil-Alana, Multi-Factor Gegenbauer Processes and European Inflation Rates, May 2009

2649 Henning Bohn, A Static Model for Voting on Social Security, May 2009

2650 Markus Haavio and Kaisa Kotakorpi, The Political Economy of Sin Taxes, May 2009

2651 Augusto de la Torre, María Soledad Martínez Pería and Sergio L. Schmukler, Drivers and Obstacles to Banking SMEs: The Role of Competition and the Institutional Framework, May 2009

2652 Tobias Lindhe and Jan Södersten, Dividend Taxation, Share Repurchases and the Equity Trap, May 2009

2653 Assaf Razin and Edith Sand, Migration-Regime Liberalization and Social Security: Political-Economy Effect, May 2009

2654 Yin-Wong Cheung and Hiro Ito, A Cross-Country Empirical Analysis of International Reserves, May 2009 
2643 Christian Gollier, Expected Net Present Value, Expected Net Future Value, and the Ramsey Rule, May 2009

2644 Sören Blomquist and Håkan Selin, Hourly Wage Rate and Taxable Labor Income Responsiveness to Changes in Marginal Tax Rates, May 2009

2645 Dominique Demougin, Oliver Fabel and Christian Thomann, Implicit vs. Explicit Incentives: Theory and a Case Study, May 2009

2646 Francesco C. Billari and Vincenzo Galasso, What Explains Fertility? Evidence from Italian Pension Reforms, May 2009

2647 Kjell Arne Brekke, Karen Evelyn Hauge, Jo Thori Lind and Karine Nyborg, Playing with the Good Guys - A Public Good Game with Endogenous Group Formation, May 2009

2648 Guglielmo Maria Caporale and Luis A. Gil-Alana, Multi-Factor Gegenbauer Processes and European Inflation Rates, May 2009

2649 Henning Bohn, A Static Model for Voting on Social Security, May 2009

2650 Markus Haavio and Kaisa Kotakorpi, The Political Economy of Sin Taxes, May 2009

2651 Augusto de la Torre, María Soledad Martínez Pería and Sergio L. Schmukler, Drivers and Obstacles to Banking SMEs: The Role of Competition and the Institutional Framework, May 2009

2652 Tobias Lindhe and Jan Södersten, Dividend Taxation, Share Repurchases and the Equity Trap, May 2009

2653 Assaf Razin and Edith Sand, Migration-Regime Liberalization and Social Security: Political-Economy Effect, May 2009

2654 Yin-Wong Cheung and Hiro Ito, A Cross-Country Empirical Analysis of International Reserves, May 2009 
2643 Christian Gollier, Expected Net Present Value, Expected Net Future Value, and the Ramsey Rule, May 2009

2644 Sören Blomquist and Håkan Selin, Hourly Wage Rate and Taxable Labor Income Responsiveness to Changes in Marginal Tax Rates, May 2009

2645 Dominique Demougin, Oliver Fabel and Christian Thomann, Implicit vs. Explicit Incentives: Theory and a Case Study, May 2009

2646 Francesco C. Billari and Vincenzo Galasso, What Explains Fertility? Evidence from Italian Pension Reforms, May 2009

2647 Kjell Arne Brekke, Karen Evelyn Hauge, Jo Thori Lind and Karine Nyborg, Playing with the Good Guys - A Public Good Game with Endogenous Group Formation, May 2009

2648 Guglielmo Maria Caporale and Luis A. Gil-Alana, Multi-Factor Gegenbauer Processes and European Inflation Rates, May 2009

2649 Henning Bohn, A Static Model for Voting on Social Security, May 2009

2650 Markus Haavio and Kaisa Kotakorpi, The Political Economy of Sin Taxes, May 2009

2651 Augusto de la Torre, María Soledad Martínez Pería and Sergio L. Schmukler, Drivers and Obstacles to Banking SMEs: The Role of Competition and the Institutional Framework, May 2009

2652 Tobias Lindhe and Jan Södersten, Dividend Taxation, Share Repurchases and the Equity Trap, May 2009

2653 Assaf Razin and Edith Sand, Migration-Regime Liberalization and Social Security: Political-Economy Effect, May 2009

2654 Yin-Wong Cheung and Hiro Ito, A Cross-Country Empirical Analysis of International Reserves, May 2009 
2643 Christian Gollier, Expected Net Present Value, Expected Net Future Value, and the Ramsey Rule, May 2009

2644 Sören Blomquist and Håkan Selin, Hourly Wage Rate and Taxable Labor Income Responsiveness to Changes in Marginal Tax Rates, May 2009

2645 Dominique Demougin, Oliver Fabel and Christian Thomann, Implicit vs. Explicit Incentives: Theory and a Case Study, May 2009

2646 Francesco C. Billari and Vincenzo Galasso, What Explains Fertility? Evidence from Italian Pension Reforms, May 2009

2647 Kjell Arne Brekke, Karen Evelyn Hauge, Jo Thori Lind and Karine Nyborg, Playing with the Good Guys - A Public Good Game with Endogenous Group Formation, May 2009

2648 Guglielmo Maria Caporale and Luis A. Gil-Alana, Multi-Factor Gegenbauer Processes and European Inflation Rates, May 2009

2649 Henning Bohn, A Static Model for Voting on Social Security, May 2009

2650 Markus Haavio and Kaisa Kotakorpi, The Political Economy of Sin Taxes, May 2009

2651 Augusto de la Torre, María Soledad Martínez Pería and Sergio L. Schmukler, Drivers and Obstacles to Banking SMEs: The Role of Competition and the Institutional Framework, May 2009

2652 Tobias Lindhe and Jan Södersten, Dividend Taxation, Share Repurchases and the Equity Trap, May 2009

2653 Assaf Razin and Edith Sand, Migration-Regime Liberalization and Social Security: Political-Economy Effect, May 2009

2654 Yin-Wong Cheung and Hiro Ito, A Cross-Country Empirical Analysis of International Reserves, May 2009 
2643 Christian Gollier, Expected Net Present Value, Expected Net Future Value, and the Ramsey Rule, May 2009

2644 Sören Blomquist and Håkan Selin, Hourly Wage Rate and Taxable Labor Income Responsiveness to Changes in Marginal Tax Rates, May 2009

2645 Dominique Demougin, Oliver Fabel and Christian Thomann, Implicit vs. Explicit Incentives: Theory and a Case Study, May 2009

2646 Francesco C. Billari and Vincenzo Galasso, What Explains Fertility? Evidence from Italian Pension Reforms, May 2009

2647 Kjell Arne Brekke, Karen Evelyn Hauge, Jo Thori Lind and Karine Nyborg, Playing with the Good Guys - A Public Good Game with Endogenous Group Formation, May 2009

2648 Guglielmo Maria Caporale and Luis A. Gil-Alana, Multi-Factor Gegenbauer Processes and European Inflation Rates, May 2009

2649 Henning Bohn, A Static Model for Voting on Social Security, May 2009

2650 Markus Haavio and Kaisa Kotakorpi, The Political Economy of Sin Taxes, May 2009

2651 Augusto de la Torre, María Soledad Martínez Pería and Sergio L. Schmukler, Drivers and Obstacles to Banking SMEs: The Role of Competition and the Institutional Framework, May 2009

2652 Tobias Lindhe and Jan Södersten, Dividend Taxation, Share Repurchases and the Equity Trap, May 2009

2653 Assaf Razin and Edith Sand, Migration-Regime Liberalization and Social Security: Political-Economy Effect, May 2009

2654 Yin-Wong Cheung and Hiro Ito, A Cross-Country Empirical Analysis of International Reserves, May 2009 